\title{
An Examination of Pre-service Mathematics Teachers' Perceptions of Mathematics Learning Activities *
}

\author{
Çağla TOPRAK** \\ Gökçe TUNCER ${ }^{* * * *}$
}

\author{
Işıkhan UĞUREL ${ }^{* * * *}$ \\ Melike YİĞITT KOYUNKAYA ${ }^{* * * * *}$
}

Received: 13 August 2015

Accepted: 08 April 2016

\begin{abstract}
In our country, one of the important concepts proposed by the recent curricula has been 'activities' since 2005. From this point of view, both mathematics educators and teachers should focus on and discuss about the importance of activities. This study is designed to examine pre-service secondary mathematics teachers' (PSMTs) perceptions about mathematics learning activities (MLA). Participants are twenty-seven PSMTs. The data include 3 different groups. The first group consists of PSMTs' free writings that describe their definitions of MLA. The second group consists of observation notes of the class discussions which are related to the structure of MLA and MLA's required properties. The last one consists of MLA samples that were designed by PSMTs. In consequence of data analysis, results show that PSMTs did not reach consensus on a unique definition or particular properties of MLA; the definitions spreaded out a broad perspective. PSMTs defined the activity as the classroom application that is connected with real life and other disciplines, compatible with the objectives in teaching programs, is designed to improve students' cognitive skills, student-centered, interesting, easy to learn, and appropriate for groupwork. But, it is found out that PSMTs did not reflect the properties of MLA while they were designing the activities. The results of the study indicated that PSMTs' perceptions of activities and their skills of designing an activity must be improved.
\end{abstract}

Keywords: task, activity, perception of an activity, mathematics learning activity (MLA), pre-service mathematics teachers, mathematics education.

\section{Extended Abstract}

Purpose and Significance: In our country, activites play an important role in the Teaching Programs published by Ministry of National Education (MoNE). Regarding the importance of the activities, teachers and students' roles as well as the teachinglearning processes were redefined in our country. Teachers were taken from the position of teaching and took placed to the position of "helper" in order to show the ways of learning of mathematics to students (Saylan \& Yurdakul, 2005). At the same time, students moved from passive position to active position, and they started to take the responsibility of their own learning of mathematics (Umay, Duatepe, \& Akkuş-Cıkla,

\footnotetext{
* This study is a part of the first author's master's thesis entitled, "Determining pre-service mathematics teachers' perceptions \& skills regarding the design of learning activities" and completed at Dokuz Eylul University.

** Mathematics Teacher, Ministry of National Education, İzmir, Turkey, cgl.tprk@ gmail.com

*** Corresponding Author: Assoc. Prof. Dr., Dokuz Eylul University, İzmir, Turkey, isikhan.ugurel@ deu.edu.tr

**** Mathematics Teacher, Ministry of National Education, İzmir, Turkey, gkctncr@ gmail.com

***** Assist. Prof. Dr., Dokuz Eylul University, İzmir, Turkey, melike.koyunkaya@deu.edu.tr
}

\section{Citation Information}

Toprak, Ç., Uğurel, I., Tuncer, G., \& Yiğit Koyunkaya, M. (2017). Matematik öğretmen adaylarinin matematik öğrenme etkinliğine yönelik algılarının incelenmesi. Kuramsal Eğitimbilim Dergisi [Journal of Theoretical Educational Science], 10(1), 1-30. 
2005). When students took the center place in learning of mathematics, the importance of mathematics learning activities sharply increased in mathematics education.

It is possible to consider the MoNe Teaching Programs and text books in terms of the duties assigned to teachers which are called as "activity based learning/teaching" (Ekici, Yıldırım, Akın, Oter, \& Ozdaş, 2010). As the importance of activities in teaching and learning process has increased recently, so mathematics educators and mathematics teachers should emphasize, discuss, consider and focus on Mathematics Learning Activity (MLA), and put it to the center of teaching and learning of mathematics. From this point of view, this study is designed to identify and examine pre-service secondary mathematics teachers' (PSMTs) perceptions about MLA and their performance on designing MLA. Specifically, the researchers illustrate PSMTs' perceptions of MLA, their thoughts about the properties of MLA, and how PSMTs' perceptions of MLA related to the activities that they designed.

Methods: Qualitative research methodology was used in this study. The study was a case study to reveal PSMTs' perceptions of MLA. Participants were 27 PSMTs from a public university in Turkey. These PSMTs were taking Special Teaching Methods II course while they participated in this study. The course was designed in order to introduce MLA, properties of MLA, and to teach how to design MLA. The PSMTs took many mathematics and mathematics education courses before participated in this study.

The data was collected in 3 phases. First phase consisted of PSMTs' free writings that describe their definitions of the MLA concept, second phase consisted of observation notes of the class discussions, and the last phase consisted of MLA that were designed by PSMTs. These observation notes that were taken by the researchers during the course were also used as the data of the study. All collected data were analyzed using content analysis method.

Results: Results of the study show that PSMTs' perceptions of MLA were related to their thoughts about the properties of MLA. In other words, they relied on the properties of MLA to define MLA. It is also identified that all PSMTs used at least two properties of MLA to define it. PSMTs did not have a unique definition to define MLA; their definitions spreaded out to a broad perspective. They defined the MLA as a structure that gives an opportunity to students in order to construct mathematical knowledge and using this knowledge later when it is necessary. They also indicated that MLA includes real world and other disciplines connections, improves cognitive skills such as mathematical thinking, reasoning, problem solving, abstraction and modelling, is constructed in the light of constructivism, is related to objectives in the teaching programs, motivates students, gives an opportunity to students in order to work in groups.

After PSMTs completed the class discussions which they discussed about what MLA is and what properties MLA should include, their perceptions regarding MLA changed. 
Specifically, they emphasized some of the points that they did not mention in their definitions. Additionally, it was found that although PSMTs defined or described some of the properties of MLA, they had difficulties while they were designing MLA. They could not reflect the components of the MLA that they used to define MLA while they were designing activities. The results show that even PSMTs had a broad perception regarding MLA, it was difficult for them to include the components of MLAwhile designing them. Specifically, even though they believed that a good MLA should include a real life example; they had struggled to use real life situations while designing MLA. Consequently, it is important to note that even if they had difficulties in constructions of MLA, it is found that the activity design skills of the PSMTs developed throughout the course.

Discussion and Conclusions: This study illuminates PSMTs' perceptions about the definition and properties of MLA, and how these PSMTs reflected their perceptions of MLA to the activities that they designed. It is found that PSMTs' perceptions of MLA spreaded out a broader perspectives when it is compared with the participants that took part in the existing studies (Aç11, 2011; Özmantar, Bozkurt, Demir, Bingölbali, \& Açı1, 2010; Uğurel, Bukova-Güzel, \& Kula, 2010).

In order to improve PSMTs and in-service mathematics teachers' perceptions and knowledge of MLA, they should be trained using a training program that would be designed based on activity based learning theories and applications. For in-service teachers, MoNE should organize seminars or courses and they could work with mathematics teacher educators to design good activities. In order to improve PSMTs' perceptions and knowledge of MLA, their undergraduate program should be changed and improved considering the importance of activity based learning in mathematics education. For instance, activity learning theories and its applications could be embedded to their current courses. Additionally, they could be given a chance to apply the activities in real classrooms, so they could have a chance to see how MLA work in learning and teaching of mathematics. As it is described, activity-based learning is in the center of learning of mathematics, so it is suggested that mathematics educators and teachers should improve their knowledge of MLA. 


\title{
Matematik Öğretmen Adaylarının Matematik Öğrenme Etkinliğine Yönelik Algılarının İncelenmesi *
}

\author{
Çağla TOPRAK** \\ Gökçe TUNCER ${ }^{* * * *}$
}

\author{
Işıkhan UĞUREL ${ }^{* * *}$ \\ Melike YİĞİT KOYUNKAYA ${ }^{* * * * * *}$
}

Makale Gönderme Tarihi: 13 Ağustos 2015

Makale Kabul Tarihi: 08 Nisan 2016

\begin{abstract}
ÖZ: Ülkemizde 2005 yllından bu yana, matematik dersi ögretim programlarında öne çıkan ana kavramlardan birisi matematik öğrenme etkinlikleridir. Etkinlikler hem alan araştırmacılarının hem de matematik öğretmenlerinin daha fazla üzerinde durması ve tartışması gereken bir kavram haline gelmiştir. Bu düşünce kapsamında, nitel araştırma paradigmasına dayalı bir araştırma tasarımı yapılmış ve matematik öğretmen adaylarını öğrenme etkinliklerine yönelik algılarının belirlenmiştir. Katılımcılar 27 ortaöğretim matematik öğretmeni adayıdır. Bu çalışmanın verileri üç gruptan oluşmaktadır. Birinci grupta katılımcıların matematik öğrenme etkinliği (MÖE) kavramını tanımladıkları bireysel serbest yazıları, ikinci grupta MÖE'nin yapısı ve özelliklerine yönelik sınıf bazında yapılan tartı̧̧maya ait araştırmacı alan notları, üçüncü grupta adaylarca geliştirilen MÖE örnekleri ve bunlara dönük sınıf içi tartışmalardaki gözlemler yer almaktadır. Yapılan analizler sonucunda ortaya çıkan bulgular katılımcıların MÖE'ye yönelik var olan algıların geniş bir dağlım gösterdiğini ve tek bir tanım ya da belirli net özellikler kümesi çerçevesinde toplanmadığını ortaya çıkarmıştır. Matematik öğretmen adayları etkinliği tanımlarken, günlük hayat ve diğer disiplinler ile ilişkilendirilmiş, öğretim programlarındaki kazanımlarla uyumlu, öğrencilerin bilişse becerilerini geliştiren, öğrenci merkezli, ilgi çeken, öğrenmeyi kolaylaşııran, grup çalışmasına uygun sınıf içi uygulamalar olarak tanımlamışlardır. Fakat öğretmen adayları geliştirmiş oldukları etkinliklere bir etkinlikte bulunması gereken bu özelliklere yeterince yer vermedikleri görülmüştür. Çalışmanın bulguları, öğretmen adaylarının etkinlik algılarının ve etknlik geliştirme becerilerinin geliştirilmesi gerektiğini göstermiştir.
\end{abstract}

Anahtar Kelimeler: etkinlik, etkinlik algısı, matematik öğrenme etkinliği, matematik öğretmen adayı, matematik eğitimi.

\section{Giriş}

Ulusal ve uluslararası platformda, matematik eğitiminde yaşanan gelişmelerin bir yansıması olarak günümüzde matematik öğrenme etkinliklerine verilen öneminin hızla arttığ1 görülmektedir. Matematik öğretim sürecinin etkinlik temelli/ merkezli bir yapıya sahip olması gerektiği hususunda hemfikir olanların sayıs1 giderek artmaktadır. Özellikle, yeni programların karakteristik yanlarından birini, öğrencinin merkezde olduğu "etkinlik temelli öğrenme" anlayışı olarak ifade etmek mümkündür. Etkinliğin eğitim ve öğretim programlarda bu denli önemli bir yer edinmesi beraberinde ülkemizde matematik eğitimi alanındaki araştırmacıların bu alana olan ilgisini arttırmıştır (örn. Aç11, 2011; Adıgüzel, 2009; Arı, Çavuş, \& Sağlık, 2010; Aslan, 2010; Bingölbali, 2010; Ocak \& Dönmez, 2010; Özmantar, Bozkurt, Demir, Bingölbali, \& Aç11, 2010; Özpolat, Sezer, İşgör, \& Sezer, 2007; Uğurel \& Bukova-Güzel, 2010; Uğurel, Bukova-Güzel, \& Kula, 2010; Uşun \& Gökçen, 2010; Yapıcı \& Leblebiciler, 2007). Bu konu üzerindeki yaklaşımlar (öğretmenlerin etkinlik hakkındaki düşüncelerini inceleyen, etkinliklerin

\footnotetext{
* Bu çalışma, birinci yazarın Dokuz Eylül Üniversitesi’nde hazırladığı “Matematik Öğretmen Adaylarının Öğrenme Etkinliklerine Yönelik Algılarının ve Etkinlik Geliştirme Becerilerinin Belirlenmesi” başlıklı yüksek lisans tezinden üretilmiştir.

** Mathematik Öğretmeni, MEB, İzmir, Türkiye, cgl.tprk@ gmail.com

**** Sorumlu Yazar: Doç. Dr., Dokuz Eylül Üniversitesi, İzmir, Türkiye, isikhan.ugurel@ deu.edu.tr

***** Mathematik Öğretmeni, MEB, İzmir, Türkiye, gkctncr@gmail.com

***** Yrd. Doç. Dr., Dokuz Eylül Üniversitesi, İzmir, Türkiye, melike.koyunkaya@ deu.edu.tr
} 
öğrencilerin matematiğe yönelik tutumlarını etkileyip etkilemediğini ortaya çıkaran, etkinliğin özelliklerini belirlemeye çalışan vb.) farklı olsa da temel amaç bugünün ve geleceğin öğretmenlerini etkinlikleri seçme, geliştirme, uygulama, uyarlama ve değerlendirme konusunda yeterli bilgi ve beceri ile donatmaktır. $\mathrm{Bu}$ amaç doğrultusunda en başta yapılması gereken şeylerden biri etkinliğe ilişkin kavramsal ve yapısal açıdan genel bir bakış kazanmak/ kazandırmak ve söz konusu bakış altında etkinliğin temel bileşenleri üzerine yoğunlaşmaktır.

Ülkemizde öğretim programları 2004 yılından itibaren Milli Eğitim Bakanlığı (MEB) tarafından yeniden yapılandırılmıştır. Yeni programlarda en büyük yenilik programın temel aldığı felsefenin değiştirilmesiyle öğrenme-öğretme süreci ve bu süreçteki öğretmen ve öğrenci rollerinin değişmiş olmasıdır. Matematik dersi öğretim programları 2005-2006 öğretim yılında uygulamaya konulmuş, (ortaöğretim programı) 2011 de revize edilmiş ve ardından 2013 yıllarında tekrar değişikliğe uğramıştır. Özellikle 2011 yılındaki öğretim programı içerisinde etkinlikler öğrenme ve öğretme sürecinin merkezinde yer almıştır. Programda, her sınıf için geçerli olan öğrenme alanı, alt öğrenme alanı, kazanım, kazanıma yönelik etkinlik ve etkinliğe yönelik açıklamalara yer verilmiştir. İlgili bölümlere ait bir örnek Şekil 1'de verilmiştir.

Şekil 1. Kazanım bazında hazırlanan etkinlik ve etkinliğe yönelik ipuçları

\begin{tabular}{|c|c|c|c|c|}
\hline \multicolumn{5}{|c|}{ 9. SINIF ÖĞRETIM PROGRAMI } \\
\hline $\begin{array}{c}\text { ALT } \\
\text { OǴRENME } \\
\text { ALANI }\end{array}$ & KAZANIMLAR & ETKі & LÍK İPUCLARI & ACYIKLAMLALAR \\
\hline 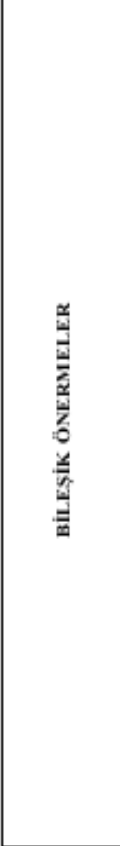 & 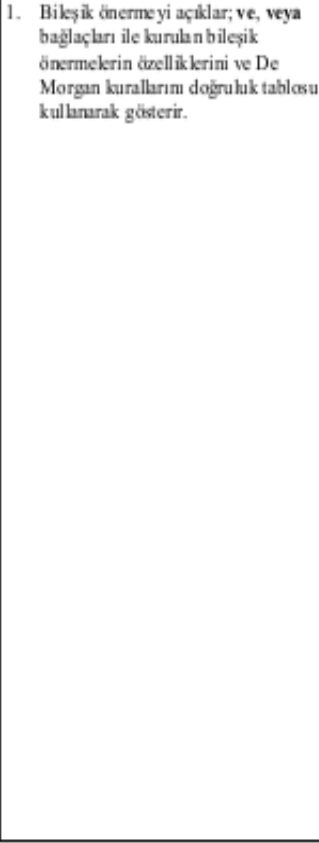 & \multicolumn{2}{|c|}{ 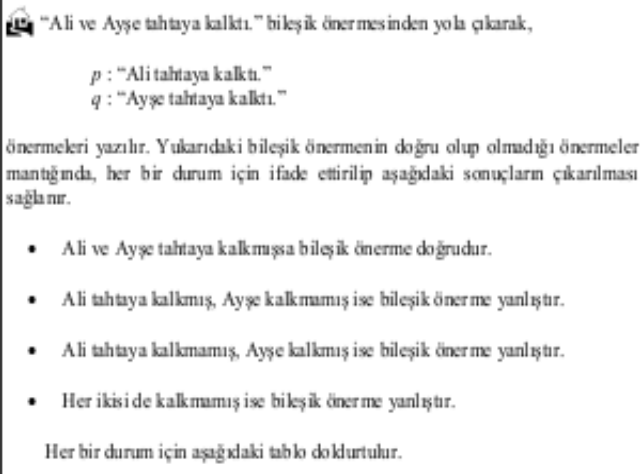 } & 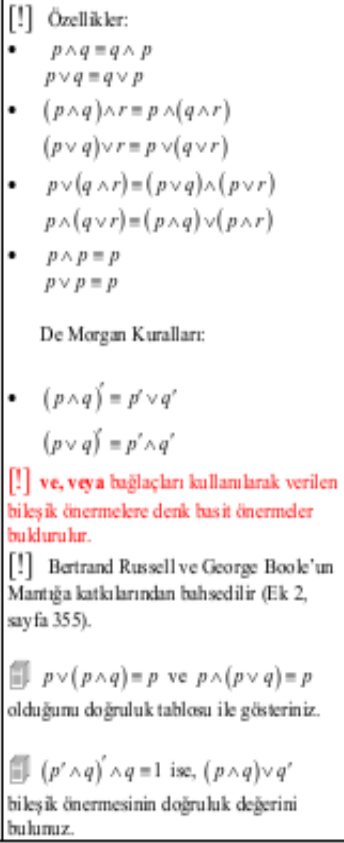 \\
\hline
\end{tabular}

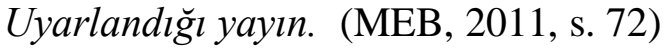


Öğretim programının geneline bakıldığında en büyük bölümün etkinliklere ayrılması, programda her sınıf bazındaki kazanımlara yönelik bir etkinlik örneği verilmesi programların etkinlik temelli görüşe göre hazırlandığının en büyük göstergesidir. $\mathrm{Bu}$ öğretim programlarında, bilginin öğretmenden öğrenciye direkt aktarılmasındansa, bilginin öğrenci tarafından inşa edilmesi esas alınmaktadır. 2011 yılında yayınlanan matematik öğretim programlarında etkinliklerin niteliği konusunda aşağıdaki konulara değinilmiştir:

- Etkinlikler sonunda öğrenilmesi istenilen özellikler, ilişkiler ve kavramlar araştırmaya ve keşfetmeye yönelik açık uçlu sorular yardımıyla etkinlikler içerisine gizlenmelidir.

- Etkinliklerin senaryoları, bireysel ve grup çalışmaları göz önüne alınarak hazırlanmalıdır.

- Etkinlikler öğrenciye aşağıdaki bilişsel süreçleri sağlamalıdır:

- Matematiksel ifadeler kullanma ve model kurma

- Mantıksal çıkarımlarda bulunma

- Matematiksel sembolleri kullanma ve soyutlama

- Öğrenmenin ön koşullarından birisi de meraktır. Etkinlikler merak uyandıracak nitelikte olmalıdır. Bu nedenle öğrenilmesi istenen özellikler, ilişkiler ve kavramlar ilgi çekici bir yaklaşımla sistemli ve planlı bir şekilde etkinliklere yansıtılmalıdır. Bu nedenle, kazanımlar için uygun ve öğrenciler için üst düzey becerilerin geliştirilmesine yönelik etkinlikler hazırlanarak geliştirilmelidir.

- Kazanmalara ulaşma, gelişimsel süreci kapsadığından, karmaşık özellik taşır. $\mathrm{Bu}$ bağlamda kazanımlara uygun geliştirilecek dinamik etkinlikler kazanımlara ulaşma sürecini kolaylaştırılabilir (MEB, 2011, ss. 21-22).

2013 yılında yayınlanan yeni ortaöğretim matematik dersi öğretim programında, etkinliklerin öğrenci merkezli öğrenmedeki önemi vurgulamış ve matematik öğretiminde yer verilmesi gerektiğine değinilmiştir. 2013 öğretim programında etkinlikler kısaca;

- Akıl yürütme, problem çözme, ilişkilendirme, iletişim kurma ve modelleme gibi programın kazandırmayı hedeflediği becerilere öğrencilerin ulaşmasında onlara yardımcı olan,

- Öğrencilerin sahip olduğu yetenek ve becerileri geliştirmeye odaklanan,

- Soyut matematiksel kavramları öğrencilerin ilgi ve merakını uyandıracak günlük hayat ya da diğer disiplinler ile ilişkilendirerek sunan,

- Öğrencilerin ulaşması istenilen sonuçlara, içerisindeki sorularla, öğrencileri sürecin içerine alarak ve kendi öğrenme sorumluluklarını almasını sağlayarak ulaştıran öğrenme birimi olarak tanımlanmaktadır.

Özellikle, öğretmenlerin sınıfa iyi yapılandırılmış etkinlikleri planlayarak gelmesinin gerekliliğine değinilmiştir (s. II). Bu doğrultuda, öğretmen adaylarının ve 
öğretmenlerin etkinlikleri tasarlama, uygulama ve değerlendirme konularındaki bilgi ve becerileri arttırılarak öğretim programının amaçlarına ulaştırılması kolaylaştırılabilir.

Ülkemizin yanı sıra, uluslararası platformdaki birçok öğretim programı ve standartlarda etkinlik temelli öğrenmenin önemi ve gerekliliğine değinilirken, matematik eğitimi alanında önemli yere sahip olan ve 1989, 1991 ve 2000 yıllarında yayınlanan National Council of Teachers of Mathematics (NCTM) standartlarma ve 2010 yılında yayınlanan ve Amerika'da son yıllarda birçok eyaletin kabul ettiği Amerika Ortak Eyalet Matematik Standartları'na (Common Core State Standards for Mathematics (CCSSM), 2010) bakıldığında da etkinliklerin önemini koruduğu görülmektedir. Tüm bunlar Artigue ve Perrin-Glorian (1991)'in de belirttiği üzere pedagojik amaçlı etkinliklerin tasarımını ve kullanımını matematik eğitiminin merkezine taşımaktadır.

Buradan hareketle, alandaki araştırmaların artmasına katkı yapmayı amaçlayan çalışmada "etkinlik" geliştirme ve uygulamada en önemli öğe olan matematik öğretmenlerinin bu konuda daha fazla bilgi edinmeleri ve etkinlikler üzerine düşünmelerini sağlamaya yardımcı olmaya çalışılmaktadır. Bu çalışmanın temel amacı, matematik öğretmen adaylarının matematik öğrenme etkinliklerine yönelik algılarını araştırmaktır. Algı, Türk Dil Kurumu tarafından "bir şeye dikkatini yönelterek o şeyin bilincine varma, idrak" olarak tanımlanmıştır (2014). Dolayısıyla araştırma konumuzu oluşturan şey öğretmen adaylarının matematik öğrenme etkinliği (MÖE)'yi ne şekilde idrak ettikleridir. Öğretmen adaylarının algılarını belirlemede tek aşamada ve tek bir veri grubunun kullanılması yerine birbiri ile ilişkili üç aşamada (bunlar yöntem bölümünde açıklanmaktadır) ve her aşamada ayrı veri grubunun toplanmasını içeren bir yaklaşım benimsenmiştir. Böylece etkinliklere yönelik algıların daha ayrıntılı ve ilişkisel şekilde belirlenmesinin mümkün olacağı düşünülmüştür. Bu kapsamda her bir aşama için birer tane olmak üzere üç tane probleme yanıt aranmıştır. Bu sorular aşağıdaki gibidir.

1- Matematik öğretmen adaylarının etkinlik kavramına yönelik düşünceleri nelerdir?

2- Matematik öğretmen adaylarının iyi bir etkinliğin sahip olması gereken özelliklere yönelik düşünceleri nelerdir?

3- Matematik öğretmen adayların geliştirdikleri matematik öğrenme etkinlikleri ile var olan düşünceleri arasındaki genel ilişkiler nasıldır?

\section{Çalışmanın Dayanağı}

Etkinlik kavramı genel kullanımda farklı anlamlar içermesiyle beraber, henüz üzerinde matematik eğitimi araştırmacılarının uzlaştığı ortak bir tanıma sahip olmayan bir kavramdır (Özmantar, Bozkurt, Demir, Bingölbali, \& Aç11, 2010; Smith \& Stein, 1998; Swan, 2007, 2008; Uğurel \& Bukova-Güzel, 2010). Bunun en önemli nedeni hem bu kavrama yüklenen çok geniş bir anlam yelpazesi olması hem de öğretim programları ve ders kitapları içerisinde yer alan örneklerinden yola çıkarak kavramın net bir tanımını 
yapmanın ya da sahip olması gereken tüm özellikleri belirlemenin mümkün olamamasidir.

Etkinlik kavramını ele alırken önce yabancı literatürde yer alan task ${ }^{*}$ kavramına değinmek gerekir. Task ve etkinlik kavramları birbiri ile yakından ilişkilidir. İngilizce task kavramı Türkçe'ye "görev” olarak çevrilebilse de içerdiği anlam bunun ötesindedir (Özmantar, Bozkurt, Demir, Bingölbali, \& Açıl, 2010). Task kavramı Özmantar ve diğerlerinin (2010) belirttiği gibi bazı çalışmalarda her türlü problem olarak ele alınmaktadır (örn. Stein \& Smith, 1998; Swan, 2007, 2008). Doyle'a (1983) göre akademik task, öğrencilerin belli bir ürünü elde etmek için ortaya koyması gereken yanıtlar ya da bu yanıtlara ulaşabilmek için kullandıkları yollardır. Doyle (1983) akademik task'ın öğrencilerin çalışmalarının üç yönüne odaklandığına değinmiştir. Bunlar; (1) öğrencilerin oluşturdukları ürünler, örneğin orijinal bir kompozisyon ya da bir dizi test sorusuna verilen yanıtlar, (2) ürünü oluşturmak için kullanılan işlemler, örneğin bir kelime listesini ezberleme veya bir kavramın örneklerinin sınıflandırma ve (3) ürünü oluştururken öğrencilerin ulaşabileceği verilenler ya da kaynaklar, örneğin öğretmen ya da örnek öğrenci tarafından yazılmış bir kompozisyon modelidir. Doyle’un (1983) akademik task tanımından hareketle, matematiksel taskı öğretme ve düşünme sürecinin çatısı olarak nitelemek mümkündür. Örneğin Stein, Gover ve Henningsen (1996), matematiksel task için ders sürecinde oldukça fazla kullanılan, öğrenme ve öğretme arasındaki bağlantıyı kuran yapı ifadesini kullanmaktadır. Brousseau'ya (2006) göre matematiksel task kompleks birden fazla aşama içeren ve keşif gerektiren bir problemdir.

Stein ve Smith (1998) matematiksel task'1 belirli bir matematiksel fikrin gelişmesini amaçlayan sınıf içi aktivitelerin bir kısmı olarak tanımlanmıştır. Bir task birden fazla ilişskili problemi ele alabilir ya da bir tane karmaşık problemin bir ders süresince çözülmesinden oluşur.

\footnotetext{
* Bu makalede etkinlik kavramı İngilizcedeki task ve activity kavramlarının ikisini birden içine alacak şekilde kullanılmıştır.
} 
Şekil 2: Matematiksel Etkinlik Aşamaları

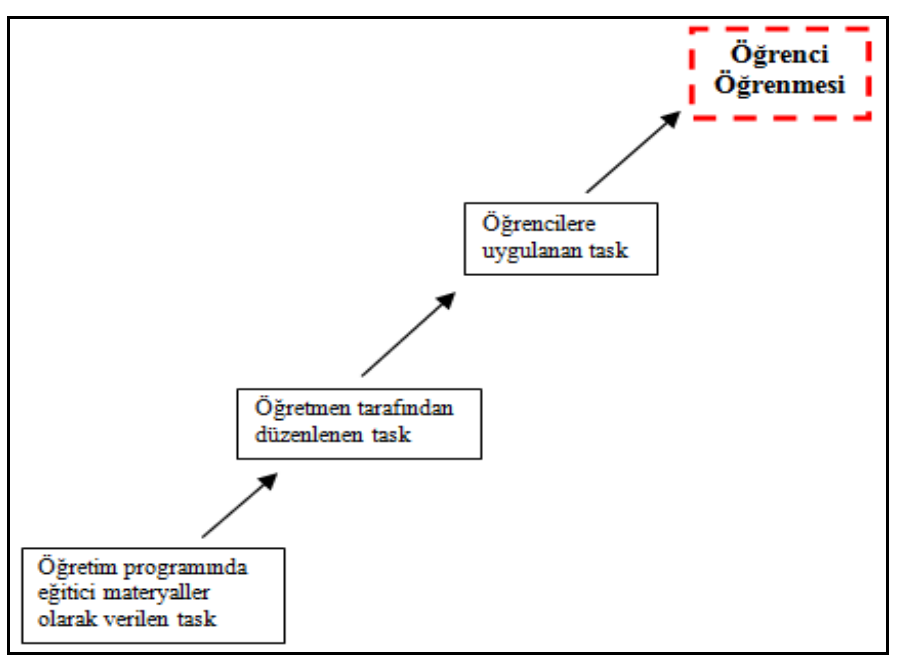

Uyarlandı ̆̆ yayın. (Stein ve Smith, 1998, s. 270)

Stein ve Smith'e (1998) göre bu şekilde tanımlanan taskların uygulanması 20-30 dakika arasında tamamlanır. Stein ve Smith (1998) task'ın etkinlik olarak nitelendirilmesi için geçmesi gereken 3 aşama olduğunu öne sürmüştür. Bu aşamalar 1müfredatta karşımıza çıkan eğitici materyaller olarak kullanılan tasklar, 2-öğretmenler tarafından verilen task-ın sinıfa göre düzenlenmesi ve son olarak 3-öğrencilere uygulanışıdır (Şekil-2). Bu aşamada, etkinliği task-ın belli bir pedagojik yaklaşımla tasarlanarak sunulması şeklinde tanımlamak mümkündür (Özmantar \& Bingölbali, 2009). Ayrıca bu varsayım Uğurel ve Bukova-Güzel (2010) tarafindan kabul edilen, Olkun ve Toluk'un (2005) etkinlik tasarlanırken sahip olunması gereken aşamalar sıralaması ile de benzeşmektedir.

Swan'a (2008) göre etkinlik; esnek, matematiksel dili geliştiren, akıl yürütmeyi gerektiren, olası kavram yanılgılarına 1şı tutacak, bireysel, tüm sınıf bazında veya işbirlikli çalışmaya izin veren, üst düzey zihinsel becerileri geliştiren, kavramları ön plana çıkaran, genellemeye fırsat veren; Ocak ve Dönmez’e (2010) göre yaratıcılığını artıran; Adıgüzel'e (2009) göre; öğrencilere bilgiye ulaşma, bilgiyi kullanma ve değerlendirme yollarını öğreten; Uğurel ve Bukova-Güzel'e (2010) göre; öğrenci merkezli, günlük yaşamla ilişkili, ilgi çekici; Bıkmaz'a (2006) göre; öğrencinin mevcut bilgilerini yeniden yapılandırmasına izin veren, yansıtıcı ve bağımsız düşünmeleri yönünde öğrencileri teşvik eden yapı olarak nitelendirilmektedir. Bu nitelemeleri arttırmak mümkündür ancak öğrenme etkinliklerinin kavramsal yapısını algılamada daha işlevsel olan yaklaşım etkinliklere (task ve etkinlik birlikte) yönelik yapılan farklı sinıflandırmaları dikkate alarak her bir sinıf bazında ve sinıflar arasında tanımlama, açıklama, karşılaştırma, geliştirme, uygulama ve değerlendirme yapmaktır. Bu sinıflandırmalardan bazıları Smith ve Stein (1998), Swan (2008) ve Uğurel ve BukovaGüzel (2010) biçiminde örneklenebilir. Araştırmamızın genelinde bu sınıflamalar dikkate alınmıştır. 
Alan yazınındaki etkinlik ve etkinlik temelli öğrenme konusundaki çalışmalara bakıldığında, ülkemizde bu çalışmaların çoğunlukla ilköğretim düzeyinde olduğu ve ele alınan konuların öğretmenlerin etkinlik hakkındaki düşüncelerini (Aç11, 2011; Adıgüzel, 2009; Özpolat, Sezer, İşgör, \& Sezer, 2007; Uğurel, Bukova-Güzel, \& Kula, 2010 [bu çalışma ortaöğretimi de kapsamaktadır]; Yapıcı \& Leblebiciler, 2007), etkinliklerin öğrencilerin matematiğe yönelik tutumlarını etkileyip etkilemediğini (Arı, Çavuş, \& Sağlık, 2010; Ocak \& Dönmez, 2010; Uşun \& Gökçen, 2010) ortaya çıkarmaya ve etkinliğin özelliklerini belirlemeye (B1kmaz, 2006; Ersoy, 2006) yönelik olduğu görülmektedir. Uluslararası platformda da etkinliklerin tasarlanması ve uygulanması ile ilgili, öğretmenlerin ve öğretmen adaylarının etkinlik konusunda farkındalık ve beceri kazanmalarını sağlamaya yönelik (Arbaugh \& Brown, 2005; Horoks \& Robert, 2007; Norton \& Kastberg, 2012; Stein \& Smith, 1998; Yeo, 2007) ve etkinliğe "task" kavram1 üzerinden yaklaşarak etkinliğe (Stein \& Smith, 1998; Swan, 2007, 2008; Yeo, 2007) yönelik olarak çalışmalar gerçekleştirilmiştir. $\mathrm{Bu}$ çalışmalar incelendiğinde, araştırmacıların uzlaştı̆̆ 1 ortak bir etkinlik tanım olmadığı, genellikle çalıştıkları konu ekseninde bir etkinliğin sahip olması gereken özelliklerden yola çıkarak etkinliği tanımladıkları görülmektedir.

Ayrıca, son yıllarda etkinlik kavramı birçok uluslararası seminer ve konferansın ana teması olarak belirlenmiş ve bu alanlara ait ilgi ve araştırmalar hızla artmıştır. Özellikle, 2013 yılında düzenlenen ICMI Study 22 oldukça önemlidir. İngiltere'de yapılan bu organizasyonun başlı̆̆ı Matematik Eğitiminde Etkinlik Tasarımı (Task Design in Mathematics Education) olup, etkinlikleri içeren araştırmaların bir çalışma grubundan yola çıkarak tek başına komple bir uluslararası bilimsel organizasyon konusunu oluşturacak boyuta geldiğini göstermektedir. $\mathrm{Bu}$ organizasyon sonucu yayınlanan ve etkinlik kavramı farklı boyutlarını ele alan kitapta, etkinlik kelimesinin farklı alanlarda farklı şekilde kullanıldığına değinilmektedir (Margolinas, 2013). Aktivite teorisinde 'etkinlik' kelimesi belirli kısıtlamalar ve koşullara dayalı olarak 'ele alınan operasyonlar' olarak tanımlanırken (Brousseau, 2006), eğitim ve öğretim açısından konuya yaklaşan araştırmacılarca (Christiansen \& Walter, 1986; Mason \& Johnston-Wilder, 2006) 'öğrencilerin yapmakla yükümlü oldukları şeyler' olarak açıklanmıştır (Margolinas, 2013). Aynı zamanda, Becker ve Shimada'nın (1997) çalışmasında olduğu gibi task 'karmaşık matematiksel etkinlikleri teşvik etme amacıyla dizayn edilen araç gereç veya öğrenme-öğretmen ortamı anlamına geldiği' ve "zengin task (rich task)" olarak adlandırıldığı görülmektedir. Task tanımı böyle verilirken, etkinlik (activity) tanımı 'öğrenci, öğretmen, bazı kaynaklar, çevre ve benzerilerinin task ile etkileşiminden ortaya çıkan matematiksel motifler/güdüler' olarak tanımlanmıştır. Buna karşı, bazı geleneksel yaklaşımlarda, etkinlik (activity) 'öğretmen tarafından hazırlanmış ve öğrencilerin belirli bir yolu ve süreci takip ederek oluşturulan durum' olarak tanımlanmaktadır (Margolinas, 2013).

Matematik öğrenme etkinliği temelli tüm araştırmalar sentezlendiğinde, matematik öğrenme etkinliğini öğrenci merkezli, günlük yaşam, diğer disiplinler ve matematiğin kendi konuları ile ilişki kurarak yapılandırılmış, bireyin matematiksel 
bilgiyi yapılandırmasına fırsat veren (yapılandırmacı öğrenme anlayışı doğrultusunda), öğrenmeyi/öğretmeyi kolaylaştıran, grup çalışması şeklinde yapılabilecek, farklı düşünme ve yaratıcılık gerektiren, matematiksel süreç becerilerini (soyutlama, çıkarımda bulunma, matematiksel düşünme, problem çözme, akıl yürütme, model kurma gibi) içeren, matematiksel sembolleri kullanmayı gerektiren, matematiğin sürekliliğini gösteren, ilgi çekici, aşamalı ve planlı olan sınıf içinde uygulamaları yapılan yapı olarak tanımlamak mümkündür.

Matematik öğrenme etkinliklerini temel alan çalışmaların öğretmenlerin etkinlik hakkındaki düşüncelerini, etkinliklerin öğrencilerin matematiğge karşı olan tutumlarını etkileyip etkilemediklerini, bir etkinliğin yapısının nasıl olması gerektiğini araştırılırken, ortaöğretim matematik öğretmen adaylarının matematik öğrenme etkinliği hakkındaki algılarını araştıran bir çalışmaya rastlanmamıştır. Bu çalışma, ortaöğretim matematik öğretmen adaylarının matematik öğrenme etkinlikleri hakkındaki var olan algılarını araştırarak, bu algıların doğru şekilde yönetilmesine ve öğretmen adaylarının etkinlik tasarlama becerisinin geliştirilmesine 1şık tutacağı umulmaktadır.

Araştırmalarda gerek öğretim programlarının gerekse içerisindeki temel öğrenme birimi olan etkinliklerin beklenen etkiyi göstermesi ve amacına ulaşması için iki önemli noktadan söz edilebileceği görülmektedir. Birincisi, etkinliklerin iyi yapılandırılması, tasarlanması ikincisi ise ondan yararlanacak olan bireylerin tutumları ve yaklaşımlarıdır (Horoks \& Robert, 2007). Öğretmenlerin öğrenme sürecinde yeni rolleri düşünüldüğünde üzerlerine düşen sorumlulukların çok daha fazla olduğu açıktır. Saylan ve Yurdakul'un (2005) da belirttiği gibi öncelikle yapılması gereken şeylerden biri öğretmenlerin kendisinden beklenenle ilgili farkındalığını artırmaktır. Bunu hem hizmet içi hem de hizmet öncesi süreçte eş zamanlı ve hıla yapmak gerekmektedir. Bu bağlamda konuya hizmet öncesi eğitim açısından yaklaşan çalışmamızın, bir yandan ortaöğretim matematik öğretmen adaylarının etkinlik konusundaki farkındalıklarını artırmaya diğer yandan alan araştırmacılarına katkı yapması beklenmektedir.

\section{Yöntem}

Bu çalışma daha geniş bir araştırmanın bir kısım öncü bulgularını kapsamaktadır ve araştırma nitel araştırma yaklaşımlarıyla gerçekleştirilmiştir. Araştırmamız öğretmen adaylarının MÖE'ye yönelik var olan algılarını ortaya çıkarmak için yapılan bir örnek olay çalışmasıdır. Örnek olay çalışmasını Yin (1984); 1-Güncel bir olguyu kendi yaşam çerçevesi (içeriği) içinde çalışan, 2-olgu ve içinde bulunduğu içerik arasındaki sınırların kesin hatlarıyla belirgin olmadığı ve 3-birden fazla kanıt veya veri kaynağının mevcut olduğu durumlarda kullanılan, görgül bir araştırma yöntemi şeklinde tanımlamaktadır (Akt: Yıldırım \& Şimşek, 2008).

$\mathrm{Bu}$ yöntemde veri toplamada dikkat edilmesi gereken dört nokta vardır. Birincisi; araştırmanın geçerliğini ve güvenirliğini önemli ölçüde artıracak (Yıldırım \& Şimşek, 2008) ve olayın bütünsel (holistik) incelenmesini sağlayan çoklu veri toplamaktır (Ekiz, 2009). Bu noktada Yin'in (1984) belirttiği gibi, dokümanlar, arşiv kayıtları, mülakatlar, doğrudan gözlem, katılımcı gözlem ve fiziksel etkiler olmak 
üzere altı farklı kaynaktan veri toplanabilir (Çepni, 2010). Çalışmamızdaki veri kaynaklarımız dokümanlardan, katılımcı gözlem notlarından, doğrudan gözlem notlarından ve fiziksel etkilerden oluşmaktadır.

\section{Katılımcilar}

Çalışmamız Türkiye'deki bir devlet üniversitesinde Ortaöğretim Matematik Öğretmenliği bölümünün 4. sınıfında öğrenim gören 27 öğretmen adayı (19 bayan, 8 bay) ile gerçekleştirilmiştir. Katılımcılar Özel Öğretim Yöntemleri-II dersi kapsamında öğrenme etkinliklerine yönelik bilgi edinme, tartışma, tasarlama ve sunma çalışmaları yapmıştır. Araştırmada bu ders ve sınıfın seçilme nedeni öğretmen adaylarının gerek alan ve gerekse pedagojik alan bilgisi açısından etkinliklere dönük çalışmalar yapabilmelerini sağlayacak ön öğrenmelere ve bir takım becerilere sahip olduklarının düşünülmesidir. $\mathrm{Bu}$ düşüncenin temel dayanağı adayların beş yıllık öğretim programı içerisinde bahar yarıyılı itibariyle Özel Öğretim Yöntemleri I, Matematik Dersi Öğretim Programları, Matematiksel Modelleme, Matematik Eğitiminde Ölçme Değerlendirme, Matematik ve Sanat, Öğretim Teknolojileri ve Materyal Geliştirme ve bilgisayar destekli matematik öğretimine yönelik bazı yazılımları ve uygulamalarını içeren (örn. Cabri, GeoGebra, Sketchpad) birtakım dersleri almış olmalarıdır. Bu dersler dikkate alınarak etkinliklere yönelik var olan literatür 1şığında araştırma aşamalı olarak planlanmış ve gerçekleştirilmiştir.

\section{Veri Toplama Süreci}

$\mathrm{Bu}$ çalışmanın verileri öğrencilere etkinlik hakkında herhangi bir bilgi vermeden öğretmen adaylarının var olan algılarını ortaya koyacak şekilde toplanmış olup üç setten oluşmaktadır. İlk aşamada öğretmen adaylarına "matematik öğrenme etkinliği” kavramından ne anladıkları sorulmuştur. Bu sorunun cevaplaması için 20 dakika süre verilmiş ve öğrencilerin bireysel cevapları yazılı olarak toplanmıştır. İki öğretmen adayı o gün derse gelmediğinden bu aşamada 25 öğretmen adayından veri toplanmıştır. İkinci aşamada sınıf bazında etkinliğin yapısı ve sahip olması gereken özellikler ile ilgili yaklaşık 60 dakika süren bir tartışma ortamı yaratılmış ve bu tartışma sonucunda üzerinde fikir birliğine varılan noktalar belirlenmiştir. Bu süreç dersi veren öğretim üyesi tarafindan yönetilmiş ve birinci araştırmacı tarafından sürece ait gözlem notları tutulmuştur. Üçüncü aşamada ise öğretmen adaylarından ortaöğretim matematik ya da geometri dersi öğretim programlarından seçecekleri herhangi bir ya da iki kazanım için 1 ya da 2 kişilik gruplar şeklinde çalışarak, her kazanım için etkinlik hazırlamaları istenmiştir. Aşamalar arasında, öğretmen adaylarına herhangi bir müdahale de bulunulmamıştır. Bu aşamalar arasında, bir eğitim verilmemiş ve öğretmen adaylarının etkinlik tasarlamalarında yönlendirme yapılmamıştır. Etkinliği geliştirmeleri için katılımcılara bir haftalık bir süre verilmiştir. Hazırlayacakları konu için bir sınırlandırma getirilmeyen katılımcılardan hazırladıkları etkinlikler için bir plan yapmaları istenmiştir. İki kişilik 11 grup, tek kişilik 5 grup olmak üzere 16 grup, toplamda 29 tane etkinlik geliştirilmiştir. Etkinliklerini geliştirdikten sonra ise tüm katılımcılar kendi etkinliklerini sınıfta tek tek sunmuştur. Bu süreçte hem etkinliğini 
sunan grubun öz değerlendirmeleri hem de etkinliği dinleyen diğer katılımcıların yorum ve eleştirileri doğrultusunda ikinci araştırmacı gözlem notu tutmuştur.

\section{Veri Analizi}

Çalışma süresince toplanan verilerin analizi nitel araştırma yaklaşımlarıyla yapılmıştır. Veri analizi sürecinde öğretmen adaylarının her birine bir numara verilmiş (ÖA1, ÖA2, ... biçiminde) ve tüm bölümlerde bu numaralar kullanılmıştır. Çalışmanın yürütüldüğg̈ dersler boyunca araştırmacılar gözlem yapmış (Yıldırım \& Şimşek, 2008), gözlem notları tutmuş ve her dersin sonunda notlar karşılaştırarak bütünleştirilmiştir. Gözlem yöntemi, nitel araştırma paradigması içerisinde en çok kullanılan yöntemlerden biridir (Ekiz, 2009). Bu yöntemde dikkat edilmesi gerekilen nokta geçerlilik ve güvenirliliktir. Bu husus Çepni'nin (2010) de belirttiği gibi iki farklı gözlemcinin somut gözlemler üzerinde anlaşabilmesi ile aşılabilir; bu noktada tutulan gözlem notları üzerinde araştırmacılar fikir birliğine vardığı için güvenilir ve geçerli olduğu kabul edilmiştir. Ayrıca çalışmamızda gözlem notları tek veri kaynă̆ı olarak kullanılmamış diğer verileri destekleyecek şekilde sunulmuştur.

Araştırmamızda ilk olarak "MÖE nedir" sorusuna verilen yazılı yanıtlar içerik analizi yöntemi ile (Berelson, 1952) analiz edilmiştir. Fiske’e (1996) göre içerik analizinin amac1; "iletilerin açık, aşikâr, içeriğinin nesnel, ölçülebilir ve doğrulanabilir bir açıklamasını yapabilmektir" (akt. Terkan, 2005). Bu çalışmada, içerik analizi yapılırken odaklanılan nokta herhangi bir sınıflamaya gitmeden öğrencilerin tanımlarında geçen özellikleri belirlemektir. Daha sonra derslerde gerçekleşen sunum ve tartışmalara ilişkin alınan gözlem notları irdelenmiştir. Ardından birinci aşamadaki verilerin analizi ile ortaya çıkan, katılımcıların MÖE tanımlarındaki özellikler kategorilere ayrılarak katılımcıların tasarladığı etkinliklerde yer alma durumu incelenmiştir.

Katılımcıların geliştirdikleri etkinliklerin analizinde de içerik analizi yöntemi kullanılmıştır. Bu çalışmada katılımcıların geliştirdikleri etkinliklerde odaklanılan nokta etkinliklerin niteliği ya da amacına uygunluğu değil, etkinliklere yüklenen anlam ve özellikler ile etkinliklerin ilişkileridir.

\section{Bulgular}

Üç gruptan oluşan verilerin ilk grubunu öğretmen adaylarının MÖE’ye yönelik tanımlarını içeren bireysel serbest yazıları oluşturmaktadır. Öğretmen adaylarının MÖE tanımları incelendiğinde, öğretmen adaylarının etkinlik tanımlarını etkinliğin sahip olması gereken özelliklerinden hareket ederek yaptıkları görülmüştür. Mesela öğretmen adayları, MÖE'yi tanımlarken günlük hayatla ilişkili, öğretim programında yer alan kazanımları gerçekleyen, aktif/ gönüllü katılım gerektiren, ilgi çekici, öğrenmeyi kolaylaştıran ve akıl yürütmeye gerektiren gibi MÖE'nin içermesi gereken özellikleri tanımlarında kullanmışlardır. Bu tanımlarda karşımıza çıkan etkinlik özellikleri Tablo 1 de detaylı olarak verilmiştir. Tabloda öğretmen adaylarının numaraları başındaki ÖA ifadeleri kullanılmadan verilmiştir ve etkinliğe ait bir özelliği ifade etme sıklığı ile birlikte sunulmuştur. 


\section{Tablo 1}

Öğrencilerin Etkinlik Tanımlarında Yer Alan Özellikler

\begin{tabular}{|c|c|c|}
\hline İfade edilen özellikler & Öğretmen adayı numarası & Siklık \\
\hline $\begin{array}{l}\text { Günlük hayatla } \\
\text { ilişkilendirme } \\
\text { (ilişkilendirme) }\end{array}$ & $2,4,6,8,9,10,12,13,15,17,20,21,22,23,24$ & 15 \\
\hline Kazanımı gerçekleme & $3,5,7,11,13,14,15,16,19,20,21,23,24,25$ & 14 \\
\hline Aktif/gönüllü katılım & $1,2,3,4,5,6,7,9,10,12,14,15,22$ & 13 \\
\hline $\begin{array}{l}\text { Disiplinler arası ilişski } \\
\text { (ilişkilendirme) }\end{array}$ & $4,6,8,12,13,15,17,21,23$ & 9 \\
\hline İlgi /dikkat çekme & $3,5,6,16,17,19,22,23,25$ & 9 \\
\hline $\begin{array}{l}\text { Öğrenmeyi } \\
\text { kolaylaştırma }\end{array}$ & $1,6,7,9,14,18,19,22,24$ & 9 \\
\hline Modelleme & $3,6,8,12,21,22$ & 6 \\
\hline Akıl yürütme & $6,12,13,16,21$ & 5 \\
\hline Kalıcı öğrenme & $10,11,14,19,22$ & 5 \\
\hline Matematiksel düşünme & $6,12,17,18,21$ & 5 \\
\hline Planlı/ programlı yapı & $9,11,13,14$ & 4 \\
\hline Anlamlı öğrenme & $9,10,20$ & 3 \\
\hline Kazanımları pekiştirme & $8,21,24$ & 3 \\
\hline Görselleştirme & $8,9,23$ & 3 \\
\hline $\begin{array}{l}\text { Ön öğrenmeleri } \\
\text { destekleme/ yararlanma }\end{array}$ & 8,15 & 2 \\
\hline Tüm sınıfı kapsayan & 4,18 & 2 \\
\hline Problem çözme becerisi & 12,13 & 2 \\
\hline Somutlaştırma & 9,22 & 2 \\
\hline Dersi zenginleştirme & 9,18 & 2 \\
\hline Eğlenceli olma & 1 & 1 \\
\hline $\begin{array}{l}\text { Birden fazla duyuya } \\
\text { hitap etme }\end{array}$ & 7 & 1 \\
\hline $\begin{array}{l}\text { Bireysel ya da grup } \\
\text { çalışmasına uygun olma }\end{array}$ & 7 & 1 \\
\hline Motive etme & 16 & 1 \\
\hline Konuyu kavratma & 18 & 1 \\
\hline $\begin{array}{l}\text { Psikomotor becerileri } \\
\text { geliştirme }\end{array}$ & 23 & 1 \\
\hline
\end{tabular}


Tablo 1 incelendiğinde öğretmen adaylarının etkinliği tanımlarken en sık kullandığ1 özelliğin günlük hayat ile etkinliğin konusunu ilişkilendirilmesi olduğu görülmektedir. Sıkça tekrarlanan diğer iki özellik ise 14 kişinin tanımında geçen etkinliğin bir ya da birden fazla kazanıma yönelik tasarlanması gerektiği ve 13 kişinin tanımında yer verdiği öğrencinin bu süreçte aktif olarak yer alması ve bunu istekli bir şekilde yapması gerektiğidir. En az değinilen özellikler ise sadece bir kişinin tanımlarında yer verdiği; etkinliğin matematiği daha eğlenceli kılan, birden çok duyu organına hitap eden, bireysel ya da grup çalışması olarak yürütülen, öğrencileri derse motive eden, konuyu kavratma amaci olan ve son olarak psikomotor becerileri barındıran yapı da olduğudur. Tablo 1'e bakıldığında tanımlamalarda siralanan özelliklerin oldukça çeşitli olduğu görülmektedir. Öğretmen adaylarının özellikleri belirtirken ilişkilendirmeyi günlük hayat ile ilişkilendirme ve disiplinler arası ilişkilendirme olarak ayrı ayrı belirtmeleri de etkinlik tanımlarında ortaya çıkan noktalardan birisidir. Ayrıca bilişsel, duyuşsal ve psikomotor becerilerin hepsine değinen özellikler mevcuttur.

Öğretmen adaylarının etkinlik kavramını tanımladıkları bireysel serbest yazılarında etkinliğe ait birden fazla özelliği bir arada kullandıkları görülmektedir. $\mathrm{Bu}$ nedenle tanımlar bu doğrultuda tekrar analiz edilmiş ve katılımcıların tanımlarında kaç özelliği birlikte kullandıği Tablo 2 de verilmiștir.

Tablo 2

Öğretmen Adaylarının Tanımlarında Kullandıkları Özellik Sayıları

\begin{tabular}{llllllll}
\hline Özellik & 8 & 7 & 6 & 5 & 4 & 3 & 2 \\
Sayısı & 2 & 3 & 3 & 4 & 7 & 4 & 2 \\
Kişi Sayısı & 2 & & & & \\
\hline
\end{tabular}

Tablo 2 görüldüğü üzere öğretmen adaylarının ikisi 8 , üçü 7, üçü 6 , dördü 5 , yedisi 4, dördü 3 ve ikisi 2 özelliğe değinmiştir. En çok özellik belirten aday sayısı iki iken, en az özelliğe değinenlerin sayısı yine 2'dir. Ayrıca en fazla sayının 4 özellik kullanan öğretmen adaylarında olduğu görülmektedir. Öğretmen adaylarının etkinlik tanımlarından bazıları Tablo 3 de verilmiştir.

Tablo 3 
Bazı Öğretmen Adaylarının MÖE Tanımları

\begin{tabular}{|c|c|}
\hline $\begin{array}{l}\text { Aday } \\
\text { Numaras1 }\end{array}$ & $\begin{array}{l}\text { Öğretmen Adaylarının } \\
\text { MÖE Tanımları }\end{array}$ \\
\hline 1 & $\begin{array}{l}\text { Matematik öğretimini daha anlaşılır, daha eğlenceli ve öğrencilerin şevklenerek } \\
\text { derse katılmasını sağlamak için yapılan uygulamalara etkinlik diyebiliriz. }\end{array}$ \\
\hline 2 & $\begin{array}{l}\text { Etkinlik, öğrencilerin aktif ve istekli oldukları gerçek yaşamla ilişkili olan öğrenme } \\
\text { süreçleridir. MÖE ise etkinliklerin matematik alanında uygulama şeklidir. }\end{array}$ \\
\hline 6 & $\begin{array}{l}\text { Etkinlik, dersi daha ilgi çekici hale getirmek, konuyu öğrenciye daha iyi } \\
\text { anlatabilmek, öğrenciyi öğrenmenin içine katabilmek için yapılan aktivitelerdir. } \\
\text { MÖE ise etkinliğin matematik dersine uyarlanmış halidir. Öğrencinin akıl yürütme, } \\
\text { modelleme vb. becerilerini geliştirmeyi hedefler. Öğrencinin matematiksel } \\
\text { düşünmesini sağlar. Daha çok günlük hayatla ilişkili olur, diğer disiplinlerle de } \\
\text { ilişkili olabilir. }\end{array}$ \\
\hline 8 & $\begin{array}{l}\text { Matematik veya yan bilimleriyle ilişkili olabilen güncel hayata uyarlanan } \\
\text { öğrenmeyi görsellik ve modelleme ile sağlayan uygulama ile konuların } \\
\text { pekiştirilmesine yarayan, dersin öncesinde de uygulanabilen programa dayalı } \\
\text { öğrenme işleridir. }\end{array}$ \\
\hline 13 & $\begin{array}{l}\text { Etkinlik, hedeflenen kazanımı öğrenciye kazandırabilmek için planlanan programlı } \\
\text { aktivite demektir. MÖE, matematik dersinin kazanımlarını öğrenciye verebilmek } \\
\text { için oluşturulan, öğrenciye problem çözme, akıl yürütme, ilişkilendirme gibi } \\
\text { beceriler kazandıran, planlı, programlı aktivitelerdir. }\end{array}$ \\
\hline 15 & $\begin{array}{l}\text { Belirli kazanımları öğrenciye kazandırmayı amaçlayan, öğrencinin aktif olarak, ön } \\
\text { öğrenmelerinden yararlanarak ve farklı alanlarla ilişkilendirme yaparak katıldığı bir } \\
\text { süreçtir. }\end{array}$ \\
\hline 22 & $\begin{array}{l}\text { Bir matematik konusunun, kavramının öğrencilere somutlaştırılarak ve konuya } \\
\text { ilgisini artırarak kavratmaktır. Etkinlik uygulanarak öğrencilerin derse katılımı } \\
\text { sağlanır. Bir matematik konusunu, günlük hayattan bir örneğe modelleyerek } \\
\text { öğrencilerin daha kolay kavraması ve öğrenmenin kalıcı olmasını sağlanır. }\end{array}$ \\
\hline
\end{tabular}

Öğretmen adaylarının MÖE'ye yönelik tanımları incelendiğinde bazı öğretmen adaylarının MÖE'yi tanımlamadan önce etkinliğin ne olduğunu tanımladığı ve bu tanıma bağlı olarak MÖE'yi etkinliğin matematikteki uygulaması olarak açıkladığı saptanmiştır.

Araştırmamızın ikinci grup verilerini, etkinliğin yapısı ve özelliklerine yönelik tüm sınıf bazında yapılan tartışma oturumuna ait araştırmacı gözlem notları oluşturmaktadır. Bu tartışma yaklaşık 60 dakika sürmüştür. Başlangıç aşamasında, 1520 dakika kadar tüm öğretmen adayları ile beyin firtınası yapılmış ve bu süre sonunda sınıfın yaygın olarak belirttiği ya da üzerinde ortak kanı oluşturduğu ifadeler tahtaya yazılmıştır. Tüm bu süreçte iki araştırmacı sınıfta bulunmuş tartışmayı izlemiş, öğretim üyesi tartışmayı yönetirken diğer bir araştırmacı gözlem notları tutmuştur. Araştırmacı gözlem notları aşağıdaki ifade edilmiştir:

"Sınıfa 'Etkinlik nedir?' ve 'Etkinliğin Sahip Olması Gereken Özellikler Nelerdir?' soruları yöneltildi. Ardından ilk önce sınıfça ilk soruya cevap bulunmaya 
çalış1ld1. $\mathrm{Bu}$ süreçte öğrencilerin tümü aktif olarak rol alarak kendi düşüncelerini belirttiler. Hocanın sınıfı konuşmaya teşvik etmesiyle düşüncelerini rahat bir şekilde açıklayan öğretmen adayları bu süreç sonunda fikir birliğine vardıkları noktaları belirlediler ve bu noktalar tahtanın bir bölümüne not edildi. Bu noktalar şu şekilde siraland1.

Etkinlik denilince akla gelen özellikler:

- Öğrencinin aktif katılım'ını sağlayacak şekilde,

- Sistematik/planlı olarak organize edilen,

- Bir ya da daha çok kazanımı veya geniş bir kazanımın bir kısmını kazandırmak için tasarlanan,

- Esnek ve geliştirilebilir bir yapıya sahip,

- Belli bir süre içerisinde gerçekleştirilmesi gereken ve

- Kavramın ya da kazanımın kazandırılıp kazandırılmadiğını ölçmek için 'Ölçme-Değerlendirme' kısmının bulunması gereken yapıdır. Ölçme işlemi için soru ya da tanımlamada istenebilir.

$\mathrm{Bu}$ konuda çoğunluğa dayalı fikir birliğine varıldıktan sonra ikinci soru ele alındı. Ve bir etkinliğin sahip olması gereken özellikler ve bir etkinliğin adaylarca beğenilme kriterlerinin neler olduğu değerlendirildi. Tartışma sonrasında ortaya çıkan beğenme kriterleri tahtaya not edildi. Bu kriterler:

1. Ilişskilendirme kalitesi / niteliği

2. Basit / net (ergonomik) olmasl,

3. Görsel yanının olması,

4. Ĕ̆lenceli (motivasyonu sağlayan) olması,

5. Teknoloji desteği bulunmasi,

6. Kazanımı karşılama düzeyi ve

7. Aktif katılım şeklinde ortaya çıktı.

Tartışma boyunca tutulan gözlem notları incelendiğinde öğretmen adaylarının etkinliğin tanımını yaparken aktif katılım, sistematik/ planlı, kazanımı gerçeklemeye yönelik, esnek ve geliştirilebilir, belli bir süre ile sınırlı ve ölçme değerlendirme kavramları üzerinde fikir birliğine vardıkları görülmektedir. Bir etkinliğin sahip olması gereken özellikler göz önüne alındığında ise, öğretmen adayları 7 özelliği öne çıkarmış ve onlar üzerinde fikir birliğine varmışlardır.

Araştırmamızın üçüncü veri grubunu öğretmen adayları tarafından geliştirilen MÖE örnekleri ve bu örneklerin sınıfta sunumu sirasında tutulan gözlem notları oluşturmaktadır. $\mathrm{Bu}$ aşamanın amacı öğretmen adaylarının etkinlik geliştirme becerilerini ve geliştirilen etkinliklerin niteliği incelemek değildir. Etkinliklere ait algıları bütüncül şekilde belirleyebilmek için, onların etkinlikler hakkında düşünme yollarını genişletmektir. Bireysel yazıları ve sınıf içi tartışma süreçlerindeki düşünceler ile etkinliği geliştirme sürecindeki düşünceler arasında (tanımlar ve özellikle 
çerçevesinde) bir devamlılık ya da değişim olup olmadığına odaklanılmıştır. Öğretmen adaylarının etkinlik geliştirirken sınırlı yaklaşımlar sergileyebileceği beklenen bir durumdur. Ancak etkinliklerde dikkate alınan noktalar örneğin; tanımlarda ve tartışmalarda sıralanan özellikler, geliştirme sürecinde dikkate alınmış mıdır? Bir kısım ya da tüm özellikler etkinliklerin yapısına yedirilebilmiş midir? Gruplar açısından bu durum farklılaşıyor mu? gibi sorulara yanıt bulmaktadır. Etkinlikler 5'i tek kişilik, 11'i ikişer kişilik olmak üzere 16 grup tarafindan oluşturulmuşlardır. Her grup kendi istekleri doğrultusunda bir ya da iki etkinlik geliştirmiştir. Toplamda geliştirilen etkinlik sayısı 29 dur. Hangi matematik konusu için etkinlik geliştirildiği, her bir konu için etkinlik geliştiren grup üyelerinin numaraları ve toplamda bir konudan kaç etkinlik geliştirildiği Tablo 4 de verilmiştir. [Tablodaki gruplar o grubu oluşturan öğretmen adaylarının numaraları kullanılarak belirtilmiştir. İki etkinlik geliştiren gruplar için gruplarının yanına parantez içerisinde etkinlik numarası yazılmıştır. Örneğin 4-17(1): 4 ve 17 numaralı öğretmen adaylarından oluşan grubun 1. etkinliğini ifade etmektedir.] Seçilen konulardan, 4'ü ortaöğretim geometri öğretim programında yer alırken 11 'i matematik öğretim programında yer almaktadır. En çok tercih edilen konular dörder grubun tercih ettiği fonksiyon, olasılık ve modüler aritmetiktir.

\section{Tablo 4}

Konulara Göre Etkinlik Oluşturan Gruplar ve Konuların Sayıca Dă̆ılımı

\begin{tabular}{llc}
\hline Seçilen Konu & Tasarlayan Grup Üyeleri & Adet \\
\hline Dik Prizma ve Piramit & $23(1)$ & 1 \\
Tam sayllar & $21(1)$ & 1 \\
Çokgenler & $21(2)$ & 1 \\
İntegral & $4-17(1)$ & 1 \\
Kombinasyon & $6-24(1)$ & 1 \\
Çember & $1-3(1)$ & 1 \\
Mutlak değer & $26-27$ & 1 \\
Dizi & $5-19(1)$ & 1 \\
Düzlem Kaplama & $18-22(2)$ & 1 \\
Mantık & $5-19(2), 9(2)$ & 2 \\
Trigonometri & $14(1), 14(2), 11-13(2)$ & 3 \\
Türev & $11-13(1), 20-25(1), 2-8(1)$ & 3 \\
Fonksiyon & $9(1), 10-12(1), 18-22(1), 1-3(2)$ & 4 \\
Olasılık & $7(1), 6-24(2), 20-25(2), 2-8(2)$ & 4 \\
Modüler Aritmetik & $7(2), 4-17(2), 15-16,10-12(2)$ & 4 \\
\hline
\end{tabular}

Öğretmen adayları tarafindan hazırlanan etkinlikler ve öğretmen adaylarının "MÖE nedir?" sorusuna verdikleri cevapların ilişkileri üzerine de bir inceleme 
yapılmıştır. Bu verilerin analizi yapılırken, söz konusu özellikler kategorilere ayrılmış ve sonra bu kategoriye giren etkinliği hazırlayan gruplar ve kaç kişinin bu özelliklere uygun etkinlik hazırladığı belirlenmiştir. Özellikleri kategorilere ayırma işleminde "MÖE nedir?" sorusu için yazılan bireysel serbest yazıların analizi ile ortaya çıkan etkinliğin sahip olması gereken özellikler incelenmiş ve benzeşme durumuna göre; 1 etkinliğin amacı, 2-uygulanışı, 3-tasarlanışı (yapı bakımından), 4-tasarlanışı (içerik bakımından) ve 5-kazandırmayı amaçladığı beceriler olmak üzere beş kategoriye ayrılmıştır. Her bir kategorinin içerdiği etkinliğin sahip olması gereken özellikler Şekil 3'te verilmiştir. Ek-2 de akıl yürütme, problem çözme ve ilişkilendirme becerilerinin kullanılmasını ve geliştirilmesine için öğretmen adayları tarafından tasarlanan etkinlik örnek olarak verilmiştir.

Şekil 3.Öğretmen Adaylarinin MÖE Tanımlarının Geliştirdikleri Etkinliklere Yansıması
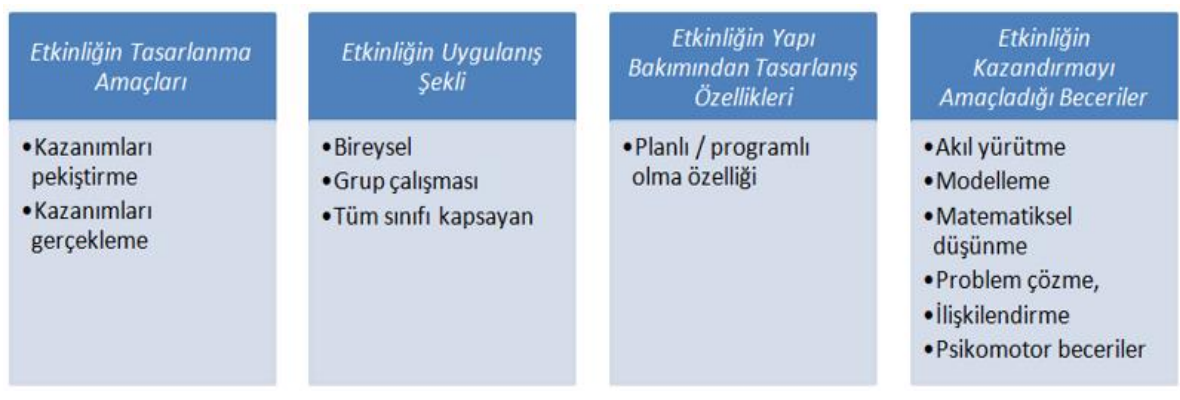

Etkinliğin Içerik
Bakımından Tasarlanıs
Özellikleri
-Günlük hayatla
ilişkilendirme
-Disiplinler arası
ilişkilendirme
-Görselleştirme
-Birden fazla duyuya
hitap etme

Öğretmen adayları tarafından belirtilen anlamlı öğrenme, kalıcı öğrenme, öğrenmeyi kolaylaştırma, matematiği daha eğlenceli hale getirme, dersi zenginleştirme, öğrencileri motive etme, öğrencide merak ve istek uyandırma özellikleri tüm etkinliklerin tasarlanma amaçlarında yer aldığından ve öğrencilerin yazılı materyallerinde değil söylemlerinde yer bulduğundan kategorileşmenin dışında bırakılmıştır. Tüm bu bilgiler ışığında Tablo 5 hazırlanmıştır.

Tablo 5

Belirtilen Özellikleri İçeren Etkinlikler ve Özelliklerin Tekrarlanma Sıklığı

\begin{tabular}{|c|c|c|}
\hline $\begin{array}{l}\text { Etkinliğin } \\
\text { Amacı }\end{array}$ & Grup Numaras1 & Toplam \\
\hline $\begin{array}{l}\text { Kazanımı } \\
\text { gerçekleme }\end{array}$ & $\begin{array}{l}9(1), 9(2), 11-13(1), 11-13(2), 4-17(1), 4-17(2), 14(1), \\
10-12(1), 1-3(2), 23,7(1), 26-27,18-22(1), 18-22(2), \\
21(2), 5-19(2)\end{array}$ & 16 \\
\hline $\begin{array}{l}\text { Kazanımı } \\
\text { pekiştirme }\end{array}$ & $\begin{array}{l}\text { 14(2), 15-16, 6-24(1), 6-24(2), 20-25(1), 20-25(2), 10- } \\
12(2), 1-3(1), 7(2), 2-8(1), 2-8(2), 21(1), 5-19(1)\end{array}$ & 13 \\
\hline $\begin{array}{l}\text { Tasarlanışı } \\
\text { (Yapı } \\
\text { Bakımından) }\end{array}$ & Grup Numaras1 & Toplam \\
\hline Plan / Program & $9(1), 9(2), 11-13(1), 11-13(2), 4-17(1), 4-17(2), 14(1)$ & 29 \\
\hline
\end{tabular}




\begin{tabular}{|c|c|c|}
\hline & $\begin{array}{l}\text { 14(2), 15-16, 6-24(1), 6-24(2), 20-25(1), 20-25(2), 10- } \\
12(2), 10-12(1), 1-3(1), 1-3(2), 23,7(1), 2-8(1), 2-8(2), \\
26-27,18-22(1), 18-22(2), 21(1), 21(2), 5-19(1), 5- \\
19(2), 7(2)\end{array}$ & \\
\hline $\begin{array}{l}\text { Kazandırmayı } \\
\text { Amaçladığı } \\
\text { Beceriler }\end{array}$ & Grup Numarası & Toplam \\
\hline Ak1l Yürütme & $\begin{array}{l}9(1), 9(2), 11-13(1), 11-13(2), 4-17(1), 4-17(2), 14(1), \\
14(2), 15-16,6-24(1), 6-24(2), 20-25(1), 20-25(2), 10- \\
12(2), 10-12(1), 1-3(1), 1-3(2), 7(1), 7(2), 2-8(1), 2- \\
8(2), 26-27,18-22(1), 21(1), 21(2), 5-19(1), 5-19(2)\end{array}$ & 27 \\
\hline Modelleme & $11-13(1), 14(2), 20-25(1), 5-19(1)$ & 4 \\
\hline $\begin{array}{l}\text { Matematiksel } \\
\text { Düşünme }\end{array}$ & $\begin{array}{l}9(1), 9(2), 4-17(1), 4-17(2), 14(2), 10-12(2), 10-12(1), \\
1-3(1), 1-3(2), 7(1), 7(2), 2-8(2), 18-22(1), 21(1), 5- \\
19(2)\end{array}$ & 15 \\
\hline $\begin{array}{l}\text { Problem } \\
\text { Çözme }\end{array}$ & $\begin{array}{l}9(1), 11-13(1), 11-13(2), 4-17(1), 4-17(2), 15-16,6- \\
24(1), 6-24(2), 20-25(2), 1-3(1), 1-3(2), 23,7(1), 7(2), \\
2-8(1), 2-8(2), 5-19(1)\end{array}$ & 17 \\
\hline $\begin{array}{l}\text { Psikomotor } \\
\text { Beceri }\end{array}$ & 23 & 1 \\
\hline İlişkilendirme & $\begin{array}{l}9(2), 11-13(1), 11-13(2), 4-17(1), 14(2), 15-16,6- \\
24(1), 6-24(2), 10-12(2), 10-12(1), 1-3(1), 1-3(2), 23, \\
2-8(1), 2-8(2), 26-27,18-22(1), 21(1), 21(2), 5-19(2)\end{array}$ & 20 \\
\hline İletişim Kurma & $10-12(1), 1-3(1), 1-3(2), 23,2-8(2), 21(1), 21(2)$ & 7 \\
\hline $\begin{array}{l}\text { Eleştirel } \\
\text { Düşünme }\end{array}$ & 23 & 1 \\
\hline $\begin{array}{l}\text { Yaratıcı } \\
\text { Düşünme }\end{array}$ & $18-22(2)$ & 1 \\
\hline $\begin{array}{l}\text { Tasarlanışı } \\
\text { (İçerik } \\
\text { Bakımından) }\end{array}$ & Grup Numarası & Toplam \\
\hline $\begin{array}{l}\text { Günlük Hayatla } \\
\text { İlişkilendirme }\end{array}$ & $\begin{array}{l}9(2), 11-13(2), 4-17(1), 4-17(2), 15-16,6-24(1), 20- \\
25(1), 20-25(2), 10-12(2), 10-12(1), 1-3(2), 23,7(1), 2- \\
8(1), 2-8(2), 26-27,18-22(1), 18-22(2), 21(1), 21(2), 5- \\
19(1)\end{array}$ & 21 \\
\hline $\begin{array}{l}\text { Disiplinler arası } \\
\text { İlişkilendirme }\end{array}$ & $11-13(1), 14(2), 1-3(1), 7(2)$ & 4 \\
\hline Görselleştirme & $14(1)$ & 1 \\
\hline $\begin{array}{l}\text { Birden fazla } \\
\text { duyuya hitap } \\
\text { etme }\end{array}$ & $14(1)$ & 1 \\
\hline
\end{tabular}


Tablo 5 incelendiğinde hazırlanan etkinliklerin 16'sının tasarlanma amacı bir kazanımı kazandırmakken, 13'ünün kazandırılan bir kazanımı pekiştirmek olduğu görülmektedir. Etkinliğin uygulanış şekli, hazırlanan 29 etkinliğin 8'inde belirtilmişken 21 'inde belirtilmemiştir. $\mathrm{Bu}$ sebeple etkinliklerin bu kategoriye göre incelenmesi yapılamamıştır. Tüm etkinlikler belli bir plan dâhilinde tasarlanmıştır. Hazırlanan etkinliklerin kazandırmayı planladığı becerilerde en çok vurgulanan 27 etkinlikte belirtilen akıl yürütmedir, bu özelliği ilişkilendirme, problem çözme ve matematiksel düşünme becerisi takip etmektedir. En az belirtilen beceriler ise psikomotor beceri, eleştirel düşünme ve yaratıcı düşünmedir. Etkinlikler tasarlanırken en çok, ele alınan konu ile günlük hayat ilişkisinin kurulmasına çalışıldığ 1 görülmektedir. Çalışma kapsamında katılımcılarca tasarlanan etkinlikleri örneklemek için iki etkinlik Ek-1 de verilmiştir.

Üçüncü veri setinin ikinci kısmı ise tasarlanan etkinlikler sınıfta sunulurken tutulan gözlem notlarıdır. Gözlem notları tutulurken katılımcıların kendi öz eleştirileri ve sınıf bazında yapılan yorum ve eleştiriler dikkate alınmıştır. Bu doğrultuda; öğretmen adayları sunumları sırasında etkinlik hazırlarken zorlandıklarını iddia ettikleri bazı noktalar saptanmıştır. Öğretmen adaylarının, bazı kazanımlar tek bir etkinlik ile ele alınamayacak kadar geniş yapıya sahip olduklarından dolayı, kazanımlara yönelik etkinlik hazırlamakta güçlük çektikleri gözlemlenmiştir. Ayrıca, öğretmen adayları seçtikleri kazanımlara ilişkin etkinlik tasarlarken etkinliklerini günlük hayat ile ilişkilendirme boyutunda zorluklarla karşılaştıklarını ifade etmelerine rağmen neredeyse tüm öğretmen adayı, etkinliklerin günlük hayat ile ilişkili olması gerektiğini düşündüklerini belirtmişlerdir. Ayrıca öğretmen adayları ölçme ve değerlendirme bölümü hazırlama konusunda da ölçme değerlendirme hazırlama kıstaslarını bilmediklerinden dolayı çeşitli zorluk yaşamışlardır. Öğretmen adayları etkinlikleri sunarken diğer gruplar etkinliklerin geliştirilmesi için çeşitli öneri ve eleştirilerde bulunmuşlardır. Bu öneri ve eleştiriler, kazanım(lar)ın çok genel olması, süre, beceri, materyal belirtilmede sıkıntı yaşama, ölçme değerlendirmenin etkinlik ile örtüşmemesi, etkinliklerde sorulan soruların çok genel olması, etkinliğin kazanımı vermede sınırlı kalması, etkinlik adımlarının açıklanmasında yetersiz kalınması, çok genel ifadeler kullanılması, adımların yeterince açıklanmaması, süre, materyal vb ifadelere yer verilmemesi, ölçme değerlendirmelerin etkinliğe hitap etmede sınırlı olması şeklinde sıralanmıştır.

\section{Sonuç ve Tartışma}

Matematik eğitiminde, bireylerde farkındalık yaratmak amacıyla, matematiksel kavramlara dair var olan algılarını belirlemek ve geliştirmek matematiksel bilginin inşasında oldukça önemli bir yere sahiptir. Bu bağlamda, bir matematiksel kavrama dair bilginin oluşması döneminde, bireylerin algılarını belirleyerek farkındalık yaratılabilir ve bu algılar doğrultusunda bir öğretim tasarım uygulaması yapılabilir. Bu çalışmada, matematik öğretmen adaylarının matematik öğrenme etkinlikleri konusunda var olan algılarına dair detaylı bir inceleme yapılmıştır. Yirmi beş öğretmen adayı, etkinliği tanımlarında yirmi beş farklı özelliğe yer vermiş̧lerdir. Her bir öğretmen adayının 
tanımında en az 2 en çok ise 8 özellik kullandığı belirlenmiştir. İki özellik kullanan katılımcıların sayısı sadece 2'dir. Bu katılımcıların diğer katılımcılara göre daha indirgeyici bir yaklaşımda oldukları aşikârdır fakat çalışmanın bu yönü alanda bu konuda yapılan diğer çalışmalarla (Açı1, 2011; Özmantar, Bozkurt, Demir, Bingölbali, \& Aç1l, 2010; Uğurel, Bukova-Güzel, \& Kula, 2010) kıyaslandığında, bu çalışmada yer alan öğretmen adaylarının etkinlik algılarının daha geniş perspektife yayıldığı görülmektedir. Bu durumun öğretmen adaylarının lisans eğitiminde aldıkları ve almakta oldukları yeni öğretim programlarını destekleyen derslerle ilişkisinin olabileceği düşünülmektedir. Çalışmanın sonuçları 1şı̆̆ında, öğretmen adaylarının eğitim süreçleri boyunca aldıkları derslerin matematik öğrenme etkinliği konusunda algılarının gelişmesinde olumlu etkileri olduğunun düşünülmesinden hareketle, lisans eğitim programlarının içerik ve kapsam olarak bu durum dikkate alınarak tasarlanmasının yararlı olacağı kanısındayız.

Öğretmen adaylarının büyük bir çoğunluğu etkinliğin öğrencinin öğrenmesi amacını taşıyan şekilde tasarlanan bir araç olduğunu ve etkinliğin bu amaca hizmet ettiğini ortaya koyan özellikleri vurgulamışlardır (öğrenme/ öğretmeyi kolaylaştırma, kalıcı öğrenme ve anlamlı öğrenmeyi sağlama, konuyu kavratma gibi). Öğretmen adaylarına göre bir etkinlik;

- Öğrencilerin dikkatini çekmeli yani ilgisini o konuya yöneltmeli,

- Birden fazla duyuya hitap etmeli böylece farklı özellikteki öğrencileri içine alabilmeli,

- Öğrenciler için matematiği daha eğlenceli kılmalı,

- Soyut kavramları somutlaştırmalı,

- Öğrencilerin ön öğrenmelerine dayanmalı,

- Öğrencilerin öğrenme işine aktif ve istekli bir şekilde katılımını sağlamalı,

- Bireysel, küçük grup çalışması ya da sınıf bazında yürütülebilecek özellikte olmalı

- Dersi zenginleştirmelidir.

Öğrenciler tarafindan farklı sıklıklarla tekrar edilen bu kavramlar birçok araştırmacının üzerinde uzlaşma sağladığı etkinliğe ait özellikler arasında yer almaktadır. Örnek olarak, Bukova-Güzel ve Alkan (2005) etkinliğin ilgi çekici olmasına, Gömleksiz (2005) bireyin bilgiyi yapılandırmasına ve bu bilgileri sonrasında uygulamasına firsat veren, Olkun ve Toluk (2005) yapılandırmacı öğrenme anlayışı doğrultusunda geliştirilen, Suzuki ve Harnish (1995) öğrencilerin iletişim kurmaları yoluyla kavramları anlamalarını sağlayan bir yapıda olmasını gerektiğini vurgulamışlardır. Ayrıca, bulgular arasında en ilgi çekici noktalardan birisi öğretmen adaylarının Stein ve Smith (1998), Horoks ve Robert (2007), Swan (2008), Ocak ve Dönmez'in de (2010) çalışmalarında vurgulandığı gibi, üst düzey zihinsel becerilere (akıl yürütme, matematiksel düşünme, problem çözme) vurgu yapmasıdır. Özellikle, Stein ve Smith (1998) tarafından etkinlikleri sınıflandırmak için geliştirilen 
sınıflandırmada olduğu gibi, öğretmen adaylarının düşüncelerinde zihinsel beceriler etkinliklerin içermesi gereken özelliklerin odak noktasında yer almaktadır. Literatürdeki etkinlik tanımları incelendiğinde, öğretmen adaylarının bir etkinlikte bulunması gereken özelliklerin birçoğuna değinmelerine rağmen yine de etkinliğe yönelik bakış açılarının etkinlik tasarlama becerilerini geliştirmek amaçlı genişletilmesi gerektiği düşünülmektedir. Bu amaç, öğretmen adaylarına yönelik etkinlik temelli öğrenmeyi temel alan bir eğitim modülü/ programı tasarlamakla ve uygulamakla mümkün olabilir. Etkinlik temelli öğrenme ve etkinlik tasarlama becerilerini geliştirmeyi amaç edinen bir öğretim modülü/ programının planının, içeriğinin ve uygulama biçiminin nasıl olması gerektiği sorusu araştırmacılara gelecekteki çalışmalara öncülük edecek bir araştırma problemi olarak bırakılmıştır.

Bukova-Güzel ve Alkan'ın (2005) çalışmalarında da belirttiği gibi, öğretmen adayları, etkinlik kavramını tanımlarken günlük hayat ile disiplinler arası ilişki boyutuna vurgu yapmışlardır. Fakat öğretmen adaylarının geliştirdikleri etkinlikler incelendiğinde, etkinlik tanımlarında disiplinler arası ilişkilendirmenin günlük hayatla ilişkilendirmenin gerisinde kaldığ 1 görülmüştür. Bunun nedeni ise öğretmen adaylarının geliştirdikleri etkinlikleri sundukları derslerde, öğretmen adaylarının söylemlerinde ortaya çıkmıştır. Katılımcı öğretmen adaylarının neredeyse hepsi etkinlik denilince kazandırılmak istenen kazanımı günlük hayat ile ilişkilendirerek ortaya koymaları gerektiği kanısına sahip oldukları gözlemlenmiştir. Bu kanının oluşma sebebini, akademik kaynaklarda ya da öğretim programlarında öğretmen adaylarının etkinliğin tanımını veya özelliklerini net bir şekilde görebilecekleri bir tanımlamayla/ örnekle karşılaşmamalarına bağlayabiliriz. Öğretmen adayları etkinliklerin günlük hayat ve diğer disiplinler ile ilişkili olması gerektiğini vurgularken, bu olguyu geliştirdikleri etkinliklere yeterince yansıtamamışlardır. $\mathrm{Bu}$ doğrultuda, öğretmen adaylarına geliştirdikleri etkinliklerde bu bağlantıyı öncülük edebilecek bir sistematik yapı veya sınıflandırmanın/ çerçevenin geliştirilmesinin yararlı olacağı düşünülmektedir. $\mathrm{Bu}$ sistematik yapının veya sınıflandırmanın geliştirilmesi bu çalışmanın yansıması olarak MÖE ile ilgilenen araştırmacılara araştırma konusu olarak önerilmektedir.

Öğretmen adaylarının MÖE’yi tanımladıkları bireysel serbest yazıları, etkinliklerin özelliklerine dair sınıf içi tartışma sonuçları ve etkinliğin beğenilme kriterleri karşılaştırıldığında üç veri grubunun arasında ortak ve farklı yanların olduğu görülmektedir. Her üç grupta ortak olarak yer alan özellikler kazanımı gerçekleştirme ve aktif katılımdır. Bireysel serbest yazılar ve beğenilme kriterlerinde ortak olan diğer bir özellik ilişkilendirmedir. Bunun yanında esnek ve geliştirilebilir olma, belli bir süre ile sınırlı olma (Stein \& Smith, 1998; Uğurel \& Bukova-Güzel, 2010) ve ölçme değerlendirme özellikleri sınıf içi tartışmada (Stein \& Smith, 1998); basit/ ergonomik ve eğlenceli olma ile teknoloji destekli olması beğenme kriterlerinde; duyuşsal alana yönelik nitelikler ile becerilere dönük (Horoks \& Robert, 2007; Smith \& Stein, 1998; Swan, 2008) özellikler bireysel serbest yazılarda ifade edilmiştir. Katılımcıların etkinliği tanımladıkları bireysel serbest yazıları ile sınıf bazında yapılan tartışma sonucu fikir birliğine varılan özellikler aynı paraleldedir. Bu durum beklenen bir durumdur. 
Dikkat çeken nokta bireysel serbest yazılarda daha dağınık olan özelliklerin sınıf bazındaki tartışmada daha toplu (temel ve tekrarlanmayan özellikleri içeren bir grup yapısında) hale gelmiş olmasıdır. Öğretmen adaylarına sorulan sorular değiştikçe öğretmen adaylarının odaklandığı noktaların farklılaştığı, etkinliğin özelliklerini/ niteliklerini içeren üç veri grubunun karşılaştırılması ile elde edilen bir diğer sonuçtur.

Öğretmen adaylarının tasarladıkları etkinlikler incelendiğinde genel özellikleri bakımından katılımcıların etkinlik tanımlarında ortaya çıkan özelliklerle benzeştiği görülmektedir. Tasarlanan etkinliklerin bir plan dâhilinde yapılması araştırmacılar tarafından talep edilmiştir. Fakat bu planın ayrıntıları katılımcılara bırakılmıştır ve sonuçta görülmüştür ki tüm katılımcılar MEB öğretim programında yer alan etkinlik örneklerinden hareketle etkinlik planını yapmışlardır. Bu durum katılımcıların etkinlik konusundaki araştırmalarını derinleştirmediğinin ve sınırlı kaynaklarla (ders kitabı, öğretim programı vb.) yetinmesinin bir sonucudur. Bu durum beklenenin tersine gelişen bir durumdur. Ayrıca, etkinlik örneklerinde göze çarpan nokta ne etkinlik tanımlarında rastlanılan ne de sınıf tartışmasında bahsedilen bazı özelliklerin (iletişim kurma, eleştirel düşünme, yaratıcı düşünme) etkinlik tasarlanırken dikkate alınmış olmasıdır. $\mathrm{Bu}$ durumun öğretmen adaylarının etkinlik geliştirme becerilerinin sınırlı olmasından ileri geldiği düşünülmektedir ki bu aynı zamanda bizim çalışmamızın da sınırlı yanlarından birini oluşturmaktadır. Adaylarca geliştirilen etkinliklerin analizi bu makale kapsamında (ele alınan araştırma sorusu nedeniyle) daha çok biçimsel düzeyde ve belirli bir özelliğin etkinlik içinde var olup olmadığını belirleme şeklinde yapılmıştır.

Çalışmamızda öğretmen adaylarının etkinliklere ilişkin algılarını belirlemek için diğer araştırmalardan farklı olarak üç aşamalı ve farklı veri gruplarının kullanılmasının oldukça yararlı olduğu görülmüştür. Aday öğretmenlerin başlangıçtaki (serbest yazma) görüşleri çok çeşitli ve dağınık iken birlikte tartışma yapma aşamasında görüşlerin gruplandığı ve özellikler üzerinde daha fazla düşünüldüğü ve bunların daha iyi kavrandığı görülmüştür. Akabinde son aşama olan etkinlik geliştirme aşamasında ise yapılan tanımlar ve sıralanan özelliklere anlam yüklemenin, onları birbiri ile ilişkilendirmenin ve belli bir organizasyon/ plan dâhilinde sunmanın kolay olmadığı ve iyi bir planlama yapmanın önemi ve gerekliliği fark edilmiştir. Böylece etkinliklere yönelik kısmi de olsa daha derin bir bakış geliştirme aşamasının başlangıcına ulaştıkları söylenebilir. Örneğin yeni bir öğrenmeyi sağlama amacı güden bir etkinlikte günlük yaşamla ilişki nasıl kurulabilir ve aynı zamanda akıl yürütme becerisi ne şekilde kazandırılabilir, etkinlik metninde anlatım ve soru-cevaplar nasıl yapılmalıdır bunların ardından ölçme nasıl yapılabilir vb. konularda birbirlerine sorular sormaları, yorum ve eleştiri getirmeleri söz konusu başlangıca yönelik emarelerdir. Çalışmada izlenen üç aşamalı yaklaşım öğretmen adaylarının algılarını bütünleme ve derinleştirmede etkili olmuştur. Tek ve değişmez bir algı yerine yine kendi etkileşimleri yoluyla genişleyen ve form kazanan bir algıya ulaştıkları görülmüştür. Bu süreçte şüphesiz en önemli şey etkileşim içinde olmaları ve düşüncelerini paylaşmalarıdır.

Diğer taraftan, öğretmen adaylarının etkinliği hem kazanımı kazandırmak hem de pekiştirmek amaçlı tasarlaması etkinliği sınırlandırmamalarının bir göstergesidir. 
Tüm öğretmen adaylarının etkinliği bir plan program dâhilinde tasarlamaları, öğretmen adaylarından başlangıçta talep edildiğinden beklenen bir sonuçtur. Fakat bunu yaparken çok yüzeysel bir plan kullanmışlar ve pek çok noktayı sunumlar sırasında sorulan sorularla aydınlatmışlardır. $\mathrm{Bu}$ durum etkinliklerin geliştirilmesi ve sınıf içi uygulamasına yönelik planlamanın önemini yeterince kavramadıklarını ancak sınıf içi sunumlarda özellikle birbirlerine sordukları sorularla fark ettiklerini göstermektedir. Ayrıca tasarlanan etkinliklerde akıl yürütme, matematiksel düşünme ve problem çözme gibi üst düzey zihinsel becerilere vurgu yapmaları ve bu becerileri öğrencilere kazandırmak için uğraşmaları son derece önem arz etmektedir. Bu beceriler pek çok araştırmacının (Horoks \& Robert 2007; Ocak \& Dönmez, 2010; Saylan \& Yurdakul, 2005; Stein \& Smith, 1988; Swan, 2008) üzerinde durduğu ve öğretim programının öğrencilere kazandırmayı planladığı becerilerdir. Etkinliklerin temelde günlük hayatla ilişkilendirilerek verilmesi ise yukarıda açıkladığı üzere öğrencilerin etkinlik kavramına yönelik bir kavramsal daraltma içerisinde olduğunu ortaya koymaktadır. Bu sınırlılık kendini etkinlik sunumları sırasında öğrenci söylemlerinde göstermiştir. Öğrenciler zorlandıkları noktaları ifade ederken bu noktalara değinmiş ve her kazanıma uygun günlük hayat ile ilişkili bir senaryo bulmakta güçlük çektiklerini belirtmişlerdir. $\mathrm{Bu}$ durum, Kavdır'ın (2011) yüksek lisans çalışmasında elde ettiği bulgularla uyuşmaktadır. Etkinliklerde mutlaka günlük yaşamla ilişki kurulması gerektiğine dair bir zorunluluk bulunmamaktadir.

Öğretmen adayları söylemlerinde rahatlıkla belirttiği kazanıma yönelik etkinlik tasarlama, günlük hayatla ilişkilendirme, etkinliğe yönelik ölçme değerlendirme bölümü hazırlama hususlarında tasarlama aşamasına geçtiklerinde zorluklarla karşılaştıklarını ifade etmişlerdir. Bu durumun temel nedenlerinden birinin öğretmen adaylarının sadece öğretim programı ve ders kitaplarında karşılaştıkları etkinlik örneklerini baz almaları ve bu konuda farklı kaynakları inceleme ya da bir araştırma yapma yolunu seçmemeleri olduğunu kanısındayız. Araştırmadaki öğretmen adaylarının diğer çalışmalardaki katılımcılardan belirgin anlayış farklılıkları mevcut olmasına (Adıgüzel, 2009; Özmantar, Bozkurt, Demir, Bingölbali, \& Aç11, 2010; Uğurel, Bukova-Güzel, \& Kula, 2010) rağmen yine de bazı noktalarda sıkıntı yaşamışlardır. Anlayış farklılıklarının temel sebebinin fakültedeki lisans öğrenimleri içerisinde değişen öğretim programlarını destekleyen eğitim alıyor olmalarına bağlanabilir.

\section{Öneriler}

$\mathrm{Bu}$ araştırmanın sonuçları, çalışmaya katılan öğretmen adaylarının önceki çalışmalarda yer alan katılımcılara göre, etkinlikleri tanımlamada ve etkinliğin sahip olduğu özellikleri belirtmelerinde daha başarılı olduğu, daha geniş bir perspektifle olaya yaklaştığını göstermektedir. Fakat öğretmen adaylarının var olan etkinlik ve MÖE algıları her ne kadar geniş bir yelpazeye yayılmış olsa da bu konuda hala (sınırlama, sınıflama ve bütünleme gibi hususlarda) kimi zorluklar yaşadıkları görüşmüştür. Öğretmen adayları her ne kadar iyi bir etkinliğin içermesi gereken özellikler konusunda fikir sahibi olsalar da bildiklerini düşündükleri birçok özelliği etkinlik tasarlamaya çalışırken aslında tam olarak açığa çıkaramadıkları görülmüştür. Araştırma sorularında 
da belirtildiği gibi, bu çalışmada matematik öğretmen adaylarının geliştirdikleri matematik öğrenme etkinlikleri ile var olan algıları arasındaki genel ilişkilerinin nası1 olduğu incelenmiştir. Bu çalışmanın akabinde, araştırmacılar öğretmen adaylarının etkinlik tanımlarındaki kavramlara, geliştirdikleri etkinlerde ne ölçüde yer verdikleri veya yer verip vermediklerini detaylı olarak inceleyerek alana katkı sağlayabilirler.

Ulaşılan sonuçlardan hareketle öğretmen adaylarının etkinlik ve MÖE algılarının geliştirmek amaçlı çalışmaların yapılması gerektiği savunulmaktadır. Matematik öğretmen adaylarının etkinlik temelli öğrenmeye yönelik bilgilerinin ve etkinlik tasarlama becerilerinin geliştirilmesi için lisans seviyesindeki öğretim programları etkinlik ve etkinlik temelli öğrenmenin önemi göz önünde bulundurularak hazırlanmalıdır. Bu yapıyı öğretmek amaçlı, öğretmen adaylarına bir ders ya da bir eğitim modülünün verilmesinin faydalı olacağı düşünülmektedir. Ayrıca, görev yapmakta olan öğretmenlerin de etkinlik algılarını geliştirmek ve iyi etkinliklerin tasarlanmasında yardımcı olmak için, etkinlik konusunda hizmet-içi eğitimler düzenlenebilir. $\mathrm{Bu}$ tür eğitimlerde özellikle öğretmen adaylarının ve öğretmenlerin kendi etkinliklerini geliştirmeleri ve mümkünse sınıflarda uygulama yapmaları da teşvik edilmelidir. Böylece sahip oldukları algıların daha doğru ve geniş bir yapıya dönüşmesi sağlanabilir. Ayrıca bu eğitimlerde, öğretmen adaylarının ve öğretmenlerin sadece öğretim programı ve ders kitaplarındaki etkinlikleri değil daha fazla etkinlik örnekleri görmeleri, incelemeleri sağlanmalıdır. Bunun için zengin etkinlik örneklerinin yer aldığ 1 kitap/ kitapçıklar hazırlanıp öğretmen ve öğretmen adaylarının hizmetine sunularak onların kavrayış ve uygulamalarına destek olunmalıdır. 


\section{Kaynakça}

Aç11, E. (2011). Illköğretim ögrretmenlerinin etkinlik algısı ve uygulanışa ilişkin görüşleri (Yayımlanmamış Y. Lisans Tezi). Gaziantep Üniversitesi Sosyal Bilimler Enstitüsü, Gaziantep.

Adıgüzel, A. (2009). Sınıf öğretmenlerinin öğrenme etkinliklerini düzenleme ve gerçekleştirme çabalarında zorlanma düzeyleri. Yüzüncü Yıl Üniversitesi Eğitim Fakültesi Dergisi, 6(11), 89-110.

Arbaugh, F., \& Brown, C. A. (2005). Analyzing mathematical tasks: A catalyst for change? Journal of Mathematics Teacher Education, 8, 499-536.

Arı, K., Çavuş, H., \& Sağlık, N. (2010). İlköğretim 6. sınıflarda geometrik kavramların öğretiminde etkinlik temelli öğrenimin öğrenci başarısına etkisi. Pamukkale Üniversitesi Ĕ̈itim Fakültesi Dergisi, 27, 99-112.

Artigue, M., \& Perrin-Glorian, M. J. (1991). Didactic engineering, research and development tool: Some theoretical problems linked to this duality. For the Learning of Mathematics, 11(1), 3-17.

Aslan, B. (2010). Matematiksel etkinliklerin uygulanması sırasında ortaya çıkan ögretmen ve ögrenci rolleri (Yayımlanmamış Y. Lisans Tezi). Gaziantep Üniversitesi Sosyal Bilimler Enstitüsü, Gaziantep.

Becker, J. P., \& Shimada, S. (1997). The open-ended approach: A new proposal for teaching mathematics. National Council of Teachers of Mathematics (NCTM), Reston, VA: NCTM.

Berelson, B. (1952). Content analysis in communication research. New York: The Free Press.

B1kmaz, F. H. (2006). New elementary curricula and teachers. Ankara University Journal of Faculty of Educational Sciences, 39(1), 97-116.

Bilgin, N. (2006). Sosyal bilimlerde içerik analizi teknikler ve örnek çalışmalar (2.bask1). Ankara: Siyasal Kitabevi.

Bingölbali, F. (2010) Matematik ögrretimi etkinlik uygulamalarında karşılaşılan öğrenci zorluklarının nedenleri ve öğretmen müdahale türleri (Yayınlanmamış yüksek lisans tezi). Gaziantep Üniversitesi.

Brousseau, G. (2006). Theory of didactical situations in mathematics: Didactique des mathématiques, 1970-1990 (Vol. 19). Springer Science \& Business Media.

Bukova-Güzel, E., \& Aklan, H. (2005). Yeniden yapılandırılan ilköğretim programının pilot uygulamasının değerlendirilmesi. Kuram ve Uygulamada Ĕgitim Bilimleri, 5(2), 385-420.

Christiansen, B. \& Walter, G. (1986). Task and activity. In B. Christiansen, A.-G. Howson \& M. Otte (Eds.), Perspectives on mathematics education: Papers submitted by members of the Bacomet Group (pp. 243-307). Dordrecht: D. Reide.

Common Core State Standards Initiative (2010). Mission statement. http://www.corestandards.org/ (23.11.2016) 
Çepni, S. (2010). Araştırma ve proje çalışmalarına giriş (4. Baskı). Ankara: Pegem Yayınc1lik.

Doyle, W. (1983). Academic work. Review of Educational Research, 53(2), 159-199.

Ekiz, D. (2009). Bilimsel araştırma yöntemleri (Geliştirilmiş 2. Baskı), Ankara: Anı Yayınc1lık.

Ersoy, Y. (2006). İlköğretim matematik öğretim programındaki yenilikler-I: Amaç, içerik ve kazanımlar. Illkögretim Online, 5(1), 30-44.

Gömleksiz, M. N. (2005). Yeni ilköğretim programının uygulamadaki etkililiğinin değerlendirilmesi. Kuram ve Uygulamada Eğitim Bilimleri Dergisi, 5(2), 339-384.

Horoks, J. \& Robert, A. (2007). Tasks designed to highlight task- activitiy relationships. Journal Math Teacher Education, 10, 279-287.

Kavdır, K. (2011). Matematik öğretmen adaylarının gerçek hayat etkinliği hazırlama süreçlerinin incelenmesi (Yayımlanmamış Y. Lisans Tezi). Gazi Üniversitesi Eğitim Bilimler Enstitüsü, Ankara.

Margolinas, C. (Ed.) (2013). Task design in mathematics education: Proceedings of ICMI Study 22. Oxford: University of Oxford.

Mason, J., \& Johnston-Wilder, S. (2006). Designing and using mathematical tasks. York, UK: QED Press.

MEB, (2011a). Ortaöğretim matematik dersi öğretim programı. Ankara: Milli Eğitim Basimevi.

MEB, (2011b). Ortaögretim 9-10. sinıflar geometri dersi öğretim programı. Ankara: Milli Eğitim Basımevi.

MEB, (2013). Ortaöğretim matematik öğretim programı. Ankara: Milli Eğitim Basımevi.

National Council of Teachers of Mathematics (1989). Curriculum and evaluation standards for school mathematics. Reston, VA: NCTM.

National Council of Teachers of Mathematics (1991). Professional standards for teaching mathematics. Reston, VA: NCTM.

National Council of Teachers of Mathematics (2000). Principles and standards for school mathematics. Reston, VA: NCTM.

Norton, A. \& Kastberg, S. (2012). Learning to pose cognitively demanding task through letter writing. Journal Math Teacher Education, 15, 109-130.

Ocak, G. \& Dönmez, S. (2010). İlköğretim 4. ve 5. sınıf öğrencilerinin matematik etkinliklerine yönelik tutum ölçeği geliştirme. Kuramsal Ĕ̆itimbilim, 3(2), 69-82.

Olkun, S. \& Toluk, Z. (2005). İlköğretimde etkinlik temelli matematik öğretimi. Ankara: Anı Yayınc1lik

Orbeyi, S. \& Güven, B. (2008). Yeni ilköğretim matematik dersi öğretim programının değerlendirme öğesine ilişkin öğretmen görüşleri. Eğitimde Kuram ve Uygulama, 4(1), 133-147. 
Özmantar, M. F. \& Bingölbali, E. (2009). Etkinlik tasarımı ve temel tasarım prensipleri. In E. Bingölbali \& M. F. Özmantar (Eds.), İlköğretimde karşılaşılan matematiksel zorluklar ve çözüm önerileri (ss. 313-348). Ankara: Pegem Akademi.

Özmantar, M.F., Bozkurt, A., Demir, S., Bingölbali, E., \& Açı1, E. (2010). Sınıf öğretmenlerinin etkinlik kavramına ilişkin algıları. Ahmet Keleşoğlu Eğitim Fakültesi Dergisi, 30, 379-398.

Özpolat, A. R., Sezer, F., İşgör, İ. Y., \& Sezer, M. (2007). Sınıf öğretmenlerinin yeni ilköğretim programına ilişkin görüşlerinin incelenmesi. Milli Eğitim, 174, 206-213.

Saylan, N. \& Yurdakul, B. (2005). Illköğretim program tasarlarının gerektirdiğ $i$ yapılandırmacı ögretmen özelliklerine sınıf ögretmenleri ile aday ögretmenlerin sahip olma düzeyleri. XIV. Ulusal Eğitim Bilimleri Kongresi, Denizli.

Smith, M. S. \& Stein, M. K. (1998). Selecting and creating mathematical tasks: from research to practice. Mathematics Teaching in the Middle School, 3(5), 344-350.

Stein, M. K. \& Smith, M. S. (1998). Mathematical tasks as a framework for reflection: from research to practice. Mathematics Teaching in the Middle School, 3(4), 268275.

Stein, M. K., Grover, B. W., \& Henningsen, M. (1996). Building student capacity for mathematical thinking and reasoning: An analiysis of mathematical tasks used in reform classrooms. American Education Research Journal, 33(2), 455-488.

Suzuki, K. \& Harnisch, D. L. (1995). Measuring cognitive complexity: an analysis of performance-based assessment in mathematics. 1995 Annual Meeting of the American Educational Research Association, San Francisco.

Swan, M. (2007). The impact of task-based professional development on teachers' practices and beliefs: A design research study. Journal of Mathematics Education, 10, 217- 237.

Swan, M. (2008). Designing a multiple representation learning experience in secondary algebra. Journal of the International Society for Design and Development in Education, 1(1), 1-17.

Terkan, B. (2005). Türkiye'de basın ve siyaset ilişkisi: basın gündemi ve siyasal gündemin karşılaştırllmasına yönelik bir gündem belirleme çalışması (Yayınlanmamış Doktora Tezi). Selçuk Üniversitesi Sosyal Bilimler Enstitüsü, Konya.

Uğurel, I., Bukova-Güzel, E., \& Kula, S. (2010). Matematik öğretmenlerinin öğrenme etkinlikleri hakkındaki görüş ve deneyimleri. Buca Eğitim Fakültesi Dergisi, 28, 103- 123.

Uğurel, I. \& Bukova-Güzel, E. (2010). Matematiksel öğrenme etkinlikleri üzerine bir tartışma ve kavramsal bir çerçeve önerisi. Hacettepe Üniversitesi Eğitim Fakültesi Dergisi, 39, 333-347. 
Uşun, S. \& Gökçen, E. (2010). İlköğretim ikinci kademede etkinlik temelli öğretim yaklaşımının öğrencilerin matematik dersine yönelik tutumlarına etkisi. International Online Journal of Educational Sciences, 2(2), 532- 561.

Umay, A. Duatepe, A., \& Akkuş-Çıkla, O. (2005). Sınıf öğretmeni adaylarının yeni ögretim programındaki matematiksel içeriğe yönelik hazır bulunuşluk düzeyleri. (456-458). XIV. Ulusal Eğitim Bilimleri Kongresi, Pamukkale Üniversitesi Eğitim Fakültesi, Denizli.

Yapıc1, M. \& Leblebiciler, N. H. (2007). Öğretmenlerin yeni ilköğretim programına ilişkin görüşleri. Illkögretim Online, 6(3), 480-490,

Yeo, J. B. W. (2007). Matehematical tasks: Clarification, classification and choice of suitable tasks for different types of learning and assessment. Mathematics and Mathematics Education National Institute of Education, 1-28.

Yıldırım, A. \& Şimşek, H. (2008). Sosyal bilimlerde nitel araştırma yöntemleri, (Genişletilmiş 6. Baskı). Ankara: Seçkin Yayıncılık. 